Florida International University

FIU Digital Commons

FIU Electronic Theses and Dissertations

University Graduate School

$10-27-2003$

\title{
Nutrient cycling in Alaskan tundra in response to experimental manipulation of growing season length and soil temperature : a climate change scenario
}

Lorraine E. Ahlquist

Florida International University

DOI: $10.25148 /$ etd.FI13101545

Follow this and additional works at: https://digitalcommons.fiu.edu/etd

Part of the Biology Commons

\section{Recommended Citation}

Ahlquist, Lorraine E., "Nutrient cycling in Alaskan tundra in response to experimental manipulation of growing season length and soil temperature : a climate change scenario" (2003). FIU Electronic Theses and Dissertations. 1163.

https://digitalcommons.fiu.edu/etd/1163 
Miami, Florida

\title{
NUTRIENT CYCLING IN ALASKAN TUNDRA IN RESPONSE TO \\ EXPERIMENTAL MANIPULATION OF GROWING SEASON LENGTH AND \\ SOIL TEMPERATURE: A CLIMATE CHANGE SCENARIO
}

\author{
A thesis submitted in partial fulfillment of the \\ requirements for the degree of \\ MASTER OF SCIENCE \\ in \\ BIOLOGY \\ by \\ Lorraine E. Ahlquist
}

2003 
To: Dean R. Bruce Dunlap

College of Arts and Sciences

This thesis, written by Lorraine E. Ahlquist, and entitled Nutrient Cycling in Alaskan Tundra in Response to Experimental Manipulation of Growing Season Length and Soil Temperature: A Climate Change Scenario, having been approved in respect to style and intellectual content, is referred to you for judgment.

We have read this thesis and recommend that it be approved.

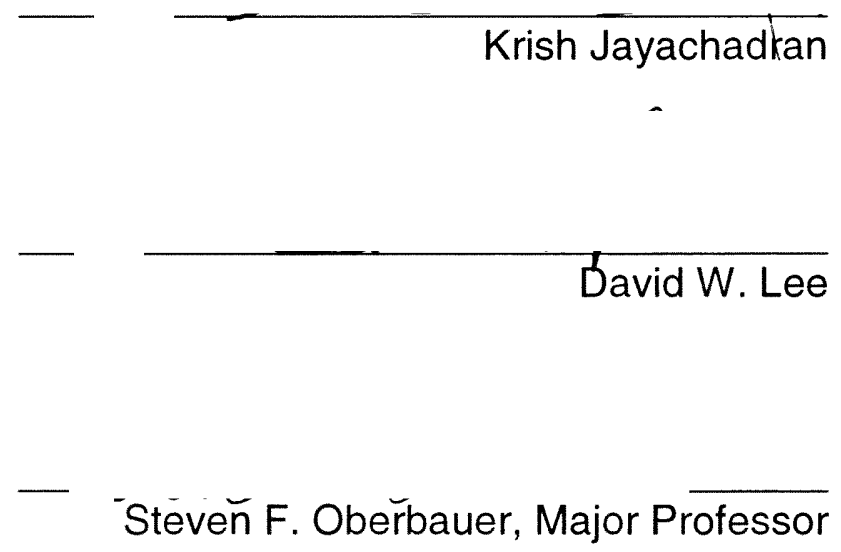

Date of Defense: 27 October 2003

The thesis of Lorraine E. Ahlquist is approved.

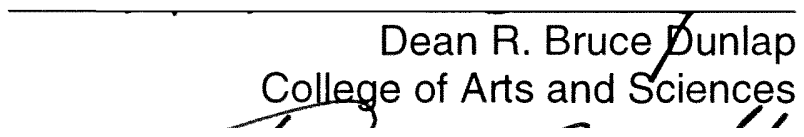

Dean Dougfas Wartzok University Graduate School

Florida International University, 2003 


\section{DEDICATION}

This thesis would be incomplete without a mention of the support given to me by my cherished parents, Earle and Betty, to whom this thesis is dedicated. They have provided me with support emotionally and financially throughout this long journey called my academic career. 


\section{ACKNOWLEDGMENTS}

A journey is easier when you travel together. Interdependence is certainly more valuable than independence. This thesis is the result of six years of work whereby I have been accompanied and supported by many people. It is with great pleasure that I now have the opportunity to express my gratitude to all of them.

The first person I would like to thank is my major professor, Dr. Steven Oberbauer. I have been involved in his project since 1997 when I started my Research Experience for Undergraduates (REU) assignment. During these years, I have known Steve as a sympathetic and principle-centered person. His conservative enthusiasm, integral view on research, and his mission for providing "only high-quality work and no less", has made a deep impression on me. I owe him lots of gratitude for showing me this way of research. He could not even realize how much I have learned from him. I am really glad that I have come to know Steve.

I would also like to thank the other members of my MS committee who monitored my work and took effort in reading and providing me with valuable comments on earlier versions of this thesis: Drs. David Lee and Krish Jayachandran. I thank you both.

I would like to thank my colleague, Dr. Gregory Starr who kept an eye on the progress of my work and was always available when I needed his advice. My colleagues of the ITEX project, for giving me a larger perspective in science. Dr. 
Gregory Starr, Eric Pop, Tracey Baldwin, Carrie Beeler, Michael Rasser, and Esperanza Rodriquez, many thanks for being my colleagues.

The statistical assistance of Paulette Johnson, who contributed substantially to the development of this work, is greatly appreciated. I would like to thank Kevin Whelan, for our many discussions and providing me brotherly advice, tips that helped me stay on the right track, for having shared the same office with me, and for being a good colleague during the last two years of my MS period. I would also like to thank Joseph O'Brien and Flavio Moreno, who visited from tropical research projects, and with whom I had many discussions on the realm of science and life.

I had the pleasure to work with Greg, Eric, Tracey, Leonard, Michael, Carrie, Tara, Inga, and Sarah who did their undergraduate and graduate work on our project and have been somehow beneficial to the work presented in this thesis. This study was based upon work supported by the National Science Foundation Office of Polar Programs under grants 9615845,9714103 , and 9907185 as part of the International Tundra Experiment (ITEX).

I am also grateful for the Department of Biological Sciences at Florida International University for providing me with the challenges of my educational work environment during the past years.

I feel a deep sense of gratitude for my father and mother who formed my early vision and taught me the good things that really matter in life. The inspirational guidelines of my parents still provide a persistent motivation for my journey in this 
life. I am grateful for my brother Oren, for rendering me the sense and the value of brotherhood. I am glad to call him my friend.

In my opinion, doing a MS is a sacred task and this was definitely one of the many challenges and accomplishments of my life. Additional energy and vitality for this research was provided externally through my involvement in several social activities. Ken Shin Kan that I have participating in since 1995 has played a substantial role and provided me the opportunity to center myself physically and mentally as well as meeting many good friends. Sensei Alfredo, Linda, Vincent, and Carolina, I thank you all for having shared many experiences and thoughts with me throughout the last years. A special thanks goes to Brandi Bellissima, whom I have known for more than seven years now and who demonstrated many acts of kindness along with being a trusted friend. 


\title{
ABSTRACT OF THE THESIS
}

NUTRIENT CYCLYING IN ALASKAN TUNDRA IN RESPONSE TO

EXPERIMENTAL MANIPULATION OF GROWING SEASON LENGTH AND

SOIL TEMPERATURE: A CLIMATE CHANGE SCENARIO

by

\author{
Lorraine E. Ahlquist
}

Florida International University, 2003

Miami, Florida

Professor Steven F. Oberbauer, Major Professor

Climate change in the Arctic is predicted to increase plant productivity through decomposition-related enhanced nutrient availability. However, the extent of the increase will depend on whether the increased nutrient availability can be sustained. To address this uncertainty, I assessed the response of plant tissue nutrients, litter decomposition rates, and soil nutrient availability to experimental climate warming manipulations, extended growing season and soil warming, over a 7 year period. Overall, the most consistent effect was the year-to-year variability in measured parameters, probably a result of large differences in weather and time of snowmelt. The results of this study emphasize that although plants of arctic environments are specifically adapted to low nutrient availability, they also posses a suite of traits that help to reduce nutrient losses such as slow growth, low tissue concentrations, and low tissue turnover that result in subtle responses to environmental changes. 
I. STUDY DESCRIPTION AND JUSTIFICATION................... 1 Overview....................................................... 1 Background .................................................... 2

II. NUTRIENT CYCLING IN ALASKAN TUNDRA IN RESPONSE TO EXPERIMENTAL MANIPULATION OF GROWING SEASON LENGTH AND SOIL TEMPERATURE............................ 10

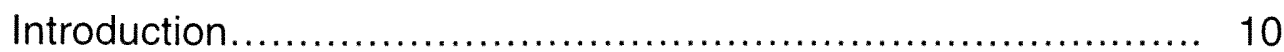

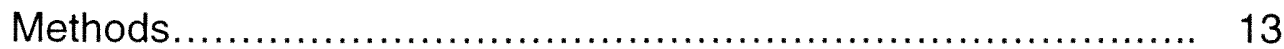

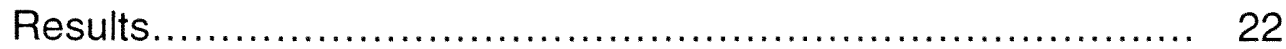

Discussion................................................... 28

III. CONCLUSIONS............................................. 57

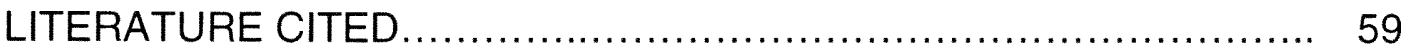


1. The selected study species and their growth forms ............. 39

2. Estimated means by year for daily air temperature ............. 40

3. Summary of microclimate properties for Toolik................... 41

4. Dates of snowmelt and snow depth at the study site ........... 42

5. Summary of ANOVA for plant tissue Carbon:Nitrogen ratio ....... 43

6. Summary of ANOVA for plant tissue Phosphorus ............... 44

7. Litter decomposition summary for final weight................... 45

8. Summary of ANOVA for soil solutions .......................... 46

9. Estimated mean concentrations ( $\mathrm{mg} / \mathrm{L}$ ) of soil solution nutrients. 47

10. Summary of ANOVA for labile ions from ion exchange .... 48

11. Potassium (K) and Phosphorus $(\mathrm{P})$ concentrations $(\mathrm{mg} / \mathrm{L})$...... 49 


\section{LIST OF FIGURES}

FIGURE

PAGE

1. Alaska map with Toolik Field Station (TFS) ................... 50

2. Plot layout of the study site ............................... 51

3. Means of daily global radiation, air temperature................ 52

4. Carbon:Nitrogen ratio for Betula nana......................... 53

5. Mean concentrations $(\mathrm{mg} / \mathrm{g})$ of tissue Phosphorus ............. 54

6. Mean concentrations of nutrients from soil solutions ........... 55

7. Mean concentrations of labile ions from ion exchange.. 56 


\section{Chapter 1.}

\section{Study description and justification}

\section{Overview}

Plant-soil interactions in the nutrient-limited arctic region are important because they will form the basis for our understanding of the carbon $(C)$ exchange between the ecosystems and the atmosphere under predicted future climatic changes. The carbon balance of the Arctic depends on the equilibrium between the $\mathrm{CO}_{2}$ uptake by primary producers and the subsequent release of $\mathrm{CO}_{2}$ through autotrophic and heterotrophic respiration (Chapin et al. 2000). This balance may change in the future in response to changes in soil-moisture conditions or temperature resulting from increases in atmospheric greenhouse gases (Flanagan and Veum 1974; Heal and French 1974; Billings et al. 1982; Billings et al. 1983; Chapin et al. 2000).

The general tendency in many arctic nutrient cycling experiments has been to experimentally manipulate the system and address questions about plant nutrient acquisition or decomposition and mineralization processes, while few studies have integrated the processes in both the soil and plant compartments (Rastetter et al. 1996). This study was an attempt to determine seasonal nutrient cycling patterns of arctic plants under conditions of simulated climate change. The results of this study will help in evaluating which species are likely to persist under the predicted rapid climate changes in the Arctic (Maxwell 1992, 1996). To 
address the uncertainty of plant and soil response to climate change, I assessed the response of plant tissue nutrients, litter decomposition rates, and soil nutrient availability to experimental climate warming manipulations, extended growing season and soil warming, over a 7 year period in arctic Alaska. The data from this project will be valuable in computer modeling of ecosystem carbon budgets of the Arctic in response to climate warming (Sitch et al. 2003). These models will help assess the future contributions of tundra ecosystems to the global carbon budget. This thesis consists of three chapters: 1) an introduction to the role of nutrient cycling in the Arctic, 2) a journal article presenting my research, and 3) a general conclusion.

\section{Background}

\section{Climate Change in the Arctic}

On a global scale, atmospheric concentrations of $\mathrm{CO}_{2}$ have been rising since the onset of the industrial revolution (Bawa and Markham 1995; Keeling et al. 1995; Cubasch 2001). This increase has been primarily attributed to fossil fuel consumption and the destruction of tropical forests (Brown 1993; Bawa and Markham 1995). Atmospheric concentrations of $\mathrm{CO}_{2}$ are predicted to double in the next three decades as a result of these anthropogenic contributions (Kerr 1988; Maxwell 1992, Keeling et al. 1995; Maxwell 1996). The increases in $\mathrm{CO}_{2}$ will significantly affect the composition of the world's terrestrial ecosystems and global carbon budget (Schimel et al. 1994). There is increasing evidence to support the idea that terrestrial systems play a major role in global primary 
productivity and, consequently, feedbacks to the global carbon cycle (Tans et al. 1990; Williams and Rastetter 1999).

GCMs predict that doubling of atmospheric $\mathrm{CO}_{2}$ will result in an average annual global warming of 1.9 to $5.2{ }^{\circ} \mathrm{C}$. This warming will be greater towards the poles. For the Arctic, the GCMs predict a winter warming at the surface 2 to 2.4 times greater than the average warming for the globe. These increases may have far reaching effects on other components of the arctic climate, such as evaporation, cloudiness, rain and snowfall. The effects of these changes on arctic plants will result in a cascade of effects through arctic ecosystems. To predict the changes to community structure and ecosystem function at these northern latitudes, we must understand the responses of tundra plants to global warming. The complexity and uncertainty associated with these predictions, including the relationships between climate elements and ecosystem components, are not well understood (Cohen 1990).

Climate changes in the Arctic may result in important changes in the snow-free season (Maxwell 1992, 1996). GCMs provide three scenarios for the effects of global warming on the arctic growing season: 1) A shortened growing season, associated with increased likelihood that snow cover will persist longer in the spring than at present, because of increased snowfall and cloud cover; 2) An extended growing season, in which the snow-free season is likely to extend further into autumn, and snow melt will occur earlier in the season; and 3) A 
growing season unchanged from the current growing season because of a combination of increased snowfall counteracted by increased snow melt. The most likely scenario is an extended season with higher temperatures, increased decomposition rates, deeper active layer, and lower water tables. Greater decomposition and unfrozen soil volume will increase nutrient availability resulting in as much as twice the present net primary production (Oechel and Billings 1992). Whether such an increase can be sustained over the long term depends on the capacity of the system to maintain elevated levels of nutrients in response to warming (Jefferies et al. 1992).

\section{Nutrient Pools in Arctic Ecosystems}

Most arctic ecosystems have high nutrient fractions in belowground biomass compared to low pools in aboveground plant biomass. Nutrients in the soil are mostly immobilized into organic pools. In ecosystems with high accumulations of soil organic matter, such as dwarf shrub tundra, the percentage of nitrogen in the soil plus litter is between 90 to 95\% (Jonasson 1982; Jonasson 1983; Jonasson and Michaelson 1996). Nutrients within the mostly slow-growing plants are held in tissues with slow turnover (Jonasson 1983; Shaver et al. 1996). Net nutrient mineralization is low and the residence time of nutrients in the soil is long. Low soil temperatures, high soil moisture, and the low quality of the organic matter strongly limit decomposition rates and nutrient mineralization in the Arctic (Flanagan and Veum 1974). Released nutrients are quickly immobilized in soil microorganisms implying that soil microbes and plants compete strongly for 
nutrients. This also implies that under conditions of declining microbial populations, microbial biomass is a potential source of nutrients.

The seasonality of nutrient mineralization often differs from the seasonality of plant nitrogen uptake. In these ecosystems where plants are dormant for most of the year, soil microbes may continue to mineralize nitrogen in unfrozen soil water during the dormant season (Bowman 1992; Giblin et al. 1991); this may lead to an accumulation of available nitrogen that plants use when they become active (Bilbrough et al. 2000). Mineralization during winter (even beneath a snowpack) may create a substantial pool of available nitrogen that is not absorbed by plants until the following spring. This asynchrony between microbial activity and plant uptake is particularly important in low-nutrient environments, where microbes may immobilize nitrogen during the season of most active plant growth, effectively competing with plants for nitrogen (Jaeger et al. 1999). In arctic soils that freeze or dry, the death of microbial cells provides additional labile substrates for mineralization when conditions again become suitable for microbial activity.

The extent of this plant-microbe competition is poorly unexplored, and it is uncertain whether plants primarily take up nutrients continuously during the summer when the sink strength is presumably strong, or whether the main nutrient uptake occurs during pulses of nutrient release when the sink strength declines. Plant storage of nutrients to support spring growth is particularly 
important in these low-fertility ecosystems because nutrients are not dependably available from the soil at times when the environment favors plant growth (Chapin et al. 1990).

Due to these conditions, arctic tundra productivity is generally nutrient limited, primarily by phosphorus and nitrogen (Haag 1974; Ulrich and Gersper 1978; Chapin 1987). This nutrient limitation favors a community dominated by plant species with low nutrient requirements or high nutrient use efficiencies (Jonasson and Chapin 1985; Berendse and Jonasson 1992; Chapin et al. 1995a).

Comparisons of elemental concentrations among tundra ecosystems indicate that weathering rates are highly individualistic, depending critically on soil parent material (Marion 1996). Furthermore, tundra ecosystems are leaky with respect to nutrients, which may have ramifications well beyond the disturbance both with respect to time and space, and bears attention in assessing the future response of tundra ecosystems.

\section{Plant Responses to Change in the Arctic}

The adaptations of the dominant plants to low nutrient availability make the system vulnerable to changes. Across the Arctic, numerous studies of plant community responses to experimental addition of nutrients, or changes in nutrient availability associated with human activity, have shown that both community productivity and plant species composition are sensitive to changes in 
the soil pools of plant available nutrients, mostly nitrogen $(N)$ and phosphorus $(P)$ (e.g. Shaver and Chapin 1980; Shaver and Chapin 1986; Jonasson 1992; Parsons et al. 1994; Forbes 1995). Thus, any changes in the input or cycling of these nutrients, as from airborne pollutants or increased rate of nutrient mineralization caused by a predicted future warming of the Arctic, if sufficiently large, will change species composition and, most likely, increase plant productivity (Cattle and Crossley 1995; Rastetter et al. 1996).

Individual species will change rather than groups of species (Chapin et al. 1997; Callaghan and Jonasson 1998). Some responses to increased nutrient supply are specific to particular growth forms (Jonasson 1992; Chapin et al. 1995b; Chapin and Shaver 1996; Callaghan and Jonasson 1998; Shaver and Jonasson 1999). The direct growth responses of evergreen dwarf shrubs to increased temperatures are small (Havström et al. 1993; Wookey et al. 1993; Chapin et al. 1995b; Chapin and Shaver 1996), in contrast to the increased growth rates of graminoids, forbs, and deciduous dwarf shrubs (Wookey et al. 1994; Henry and Molau 1997; Arft et al. 1999). In the Arctic, where these growth forms are abundant, there is a significant increase in plant biomass in response to increased temperatures in summer (Henry and Molau 1997). The response of reproductive and vegetative structures to warming will vary, depending on abiotic constraints (Wookey et al. 1994; Arft et al. 1999). Warming in the winter and spring may encourage premature growth, so subsequent frost could damage plants (Gorsuch and Oberbauer 2002). 


\section{Nutrients, Climate Change, and Ecosystem Carbon Balance in the Arctic}

Arctic ecosystems have low biomass compared with most other biomes, and vast areas are poorly vegetated or even lack vegetation. Consequently, the Arctic has the potential to act as a large sink for $\mathrm{CO}_{2}$ in the future. However, because arctic soils contain $14 \%$ of the world's stores of soil C (Post et al. 1982), the Arctic can also act as a large source of atmospheric $\mathrm{CO}_{2}$. Presumably, the changes in $\mathrm{C}$ balance are likely to be different both at local and regional scales (Callaghan and Jonasson 1995a,b).

With climate warming, high decomposition of soil organic matter paired with high nutrient immobilization, i.e. low microbial release of plant-available nutrients, may lead to a loss of carbon from the soil to the atmosphere that may not be compensated fully by increased plant $\mathrm{C}$ fixation through increased photosynthetic rates. Hence, the system will be a net source of atmospheric C. Conversely, if plants are able to sequester extra nutrients efficiently, their productivity will increase and the system may accumulate more $C$ and turn into a $C$ sink, particularly if nutrients are allocated to woody tissues of low nutrient concentrations. However, the predictions are complicated by numerous possible interactions and feedbacks between the soil and plant components. For instance, the low Arctic and sub Arctic with much higher proportions of soil C, are likely to act as sources for $\mathrm{CO}_{2}$ if changes in the environment lead to increased rate of decomposition, e.g. by warming of the soil or changed soil moisture 
conditions. At the same time, increased rates of decomposition and

mineralization will probably lead to increased $\mathrm{CO}_{2}$ uptake because plant growth generally is stimulated by increases in soil organic nutrient pools. Hence, carbon will be redistributed from the soil to the plant biomass. Because the C-to-nutrient ratio generally is higher in the plants than the soil, such redistribution would increase the ecosystem sink strength for carbon as the nutrients, particularly $\mathrm{N}$, when moved from the soil to the vegetation, enhance the ecosystem $\mathrm{C}$ fixation (Rastetter et al. 1996).

Predicted global changes in temperature and moisture regime (Kane et al. 1992), in association with indirect abiotic and biotic changes in snow cover, growing season length, nutrient availability, litter quality and community change, may strongly affect the carbon balance of arctic ecosystems (Jonasson 1995; Chapin et al. 1995b; Hobbie 1996). The processes in arctic ecosystems can also feed back to the global climate through increased decomposition of the large stock of terrestrial soil carbon (Callaghan and Jonasson 1995b), enhanced carbon uptake by increased plant production (Rastetter et al. 1996), and changes in regional energy balance resulting from changes in vegetation structural characteristics. All of these changes will depend ultimately on the ecosystem nutrient balance. 


\section{Chapter 2.}

\section{Nutrient cycling in Alaskan tundra in response to experimental manipulation of growing season length and soil temperature}

\section{Introduction}

As a result of increasing atmospheric greenhouse gases, General Circulation Models (GCMs) project that the global-average surface temperature will increase by 1.4 to $5.8^{\circ} \mathrm{C}$ over the period from 1990 to 2100 (IPCC 2001). Land areas are expected to warm more rapidly than the global average, particularly those at high latitudes during the cold season. Simulations suggest that the warming in these regions of North America will exceed global mean warming by more than $40 \%$ (IPCC 2001). Changes in season length are expected to accompany this warming, and will be especially pronounced in the Arctic, where the short growing season is currently only 8-12 wk (Maxwell 1992, 1996). Hypothesized scenarios for the Arctic include an extended season with higher temperatures, increased decomposition rates, a deepening of the active (thawed) layer from melting of permafrost, and a lowering of the water table (Rommanovsky and Osterkamp 1997, Serreze and Hurst 2000, IPCC 2001). Indeed, such changes have already been documented (Serreze et al. 2000). These changes may increase net primary productivity as a consequence of increased nutrient availability (IPCC 2001). Whether such an increase is sustainable for long periods, however, will depend on the capacity of the system to maintain elevated levels of nutrients. 
In the Arctic, the limiting nutrients in tundra are nitrogen and phosphorus. Most nutrients are bound in the soil organic matter and litter while only a small proportion is in plant biomass (Hobbie et al. 1999). In tundra ecosystems with high accumulations of organic matter, such as in dwarf shrub tundra and Betula and Salix dominated shrub tundra, the percentage of nitrogen in the soil plus litter is between 90 - 95\% (Jonasson 1982; Jonasson 1983; Jonasson and Michelsen 1996). These ecosystems often contain large pools of nutrients, but because of low annual temperatures, net mineralization is limited, leading to high residence times. Of the nutrients within plants, a high proportion is locked into tissues with slow turnover (Jonasson 1983; Shaver et al. 1996; Eckstein and Karlsson 2001). As a result, plant growth and ecosystem productivity in arctic tundra are generally nutrient limited (Haag 1974; Ulrich and Gersper, 1978; Chapin 1987, Chapin and Shaver 1996). Under these low nutrient conditions, the community is dominated by plant species with low nutrient requirements or high nutrient use efficiencies (Jonasson and Chapin, 1985; Berendse and Jonasson, 1992; Chapin et al. 1995a).

Soil temperature along with soil moisture, aeration, and litter quality control the rates of decomposition and nutrient mineralization in the Arctic. The short growing season length and generally low temperatures in the Arctic, snow cover, and topographic position largely determine soil temperature, soil moisture, and soil aeration (Sturm et al. 2001), which in turn have strong effects on plant community composition. Although vegetation characteristics can affect all of the 
factors above (Sturm et al. 2001, McGuire et al. 2002), the primary effect of community characteristics on ecosystem nutrient cycling is through litter quality, turnover rates, and their effect on nutrient availability (Hobbie et al. 1999). Consequently, changes in season length and/or soil temperatures, active layer depth and mean solar radiation will potentially have strong effects on nutrient cycling and the vegetation biomass.

Growing season length in the low Arctic is determined largely by the timing of snowmelt in the spring. As a result, growing season duration can be experimentally modified by manipulation of snow cover. As part of the International Tundra Experiment (ITEX), the SEASON project has used snow removal and soil warming in low Arctic tundra to simulate a longer, warmer growing season as predicted by GCMs. Working within that project, I combined data on litter decomposition, soil nutrient availability, and plant nutrition to understand the changes in the ecosystem nutrient balance in response to this long-term climate-warming scenario. Improved understanding of the distribution of nutrients within this nutrient-limited ecosystem in response to climate change is critical, because the coupling between nutrient dynamics and primary production will determine the long-term carbon balance of this system.

The objective of this work was to assess the response of soil nutrient availability and plant tissue nutrients to a longer growing season plus soil warming. The study species for plant tissue nutrients included members of four growth forms, 
graminoids, perennial forbs, and evergreen and deciduous shrubs (Table 1). These vascular species comprise $>90 \%$ of the vascular ground cover of the Alaska wet tussock tundra and are key in the ecosystem nutrient regimes (McKane et al. 1997).

\section{Methods}

\section{Site Description}

The study was completed over a period of 7 years, from fall 1995 through 2001 at a site near Toolik Field Station (Figure 1), Arctic Alaska in the foothills of the Brooks Range ( $68^{\circ} 38^{\prime} \mathrm{N}, 149^{\circ} 34^{\prime} \mathrm{W}$; elevation 730 m.a.s.I.). The station is operated by the University of Alaska at Fairbanks and designated a Long Term Ecological Research (LTER) and International Tundra Experiment (ITEX) site. The study site was located on an east-facing slope approximately $1.5 \mathrm{~km}$ south of the field station. The vegetation is moist tussock tundra, and the area is typical of the North Slope foothills region (Walker et al. 1989). The dominant species is Eriophorum vaginatum, a sedge that forms tussocks, or raised mounds of the current growth on top of the growth from previous years. Intertussock space is occupied by several other dominant growth forms that include dwarf deciduous and evergreen shrubs with many forms of lichens and mosses (Bliss and Matveyeva 1992). The climate is low Arctic, with a growing season of approximately nine weeks. For characteristics of soil and vegetation, see Walker et al. (1994). Nomenclature follows that of Hultén (1968). 


\section{Experimental Design}

Experimental treatments commenced in spring 1995. The plot layout (Figure 2) consisted of six blocks of three $1.5 \times 1.5 \mathrm{~m}$ plots each, with $3 \mathrm{~m}$ separating each plot. Each block contained one of each of the following treatments randomly located within the block: control $(C)$, extended season ( $E$, snow removed and plots covered to prevent snow accumulation early in the season, and plots covered late season to prevent snow accumulation and light frosts), and six extended season plots as above plus soil warming $(H$, heating accomplished with installation of cold frame heating cable installed $10 \mathrm{~cm}$ below the surface).

To accomplish the extended season treatments $(E$ and $H)$, spring snow was removed from the plots over the course of $1-1.5 \mathrm{~d}$ from May 1 to May 3. Snow was carefully removed by hand until the plant canopy protruded from the snow at which time melt proceeds very rapidly because of the change in albedo.

Removed snow was deposited uphill from the plots to provide similar water input to the plots as ambient snowmelt. Plots were kept covered with open-ended, Aframe polyethylene tents to prevent snow accumulation after snow removal until complete snowmelt on the controls occurred and danger of snowfall had passed (usually by June 10 ). The tents allow for approximately $90 \%$ of PAR (photosynthetically active radiation) to pass through. The open ends minimized air temperature increases within the tents. The ends of the tents were temporarily closed during snowfall and windstorms. Complete snowmelt on the 
control plots ranged from 13 May to 9 June over the study period $($ median $=29$ May). At the end of the season (15 August to 4 September, plots were again covered with the A-frame tents to prevent snow accumulation and light frosts. For the $\mathrm{H}$ treatment, heating cable was installed the year before treatments began (1994) to allow recovery time prior to measurements. Cables were heated for $2 \mathrm{hr}$ each day with a 1400-watt generator for a $0.4 \mathrm{MJ} \mathrm{m}^{-2} \mathrm{~d}^{-1}$ of energy input to the soil (equivalent to $20-30 \%$ of the daily soil heat flux for this vegetation during summer months) and provided a temperature increase of approximately $2^{\circ} \mathrm{C}$ over the course of the growing season. This magnitude of increase in the energy of the soil is similar to that predicted with global warming (Maxwell 1992, 1996).

In addition to the 6 treatment blocks described above, used only for nondestructive sampling, a set of 4 blocks with the same treatments was established to be used for tissue nutrient collections (Figure 2). Boardwalks were installed throughout the study site and on 3 sides of the study plots to minimize damage to the tundra during measurements.

\section{Microclimate}

Weather and soil temperature data were acquired from the micrometeorological station of the Long Term Ecological Research Project (LTER) located near Toolik Field Station. Average daily temperature, precipitation, wind speed, global 
radiation, and soil temperature at $20 \mathrm{~cm}$ depth were aquired for each day from 1 May to 30 September for $1995,1997,2000$, and 2001 field seasons.

\section{Plant Tissue Material}

Live leaf tissue was collected each year of the study to assess the concentrations needed for estimating ecosystem nutrient budgets in response to the treatments. Three to five collections of plant tissue material were made each year on the primary study plots $(n=6)$ spread evenly over the growing season (approximately every 3 wk from early June to mid August), beginning as soon as depth of thaw was sufficient. There were three collections in 1995, five in 1997, and four in 2000 and 2001 . Live leaf tissue (5-30 mg dry weight) was collected from each of the destructive plots $(n=4)$ by clipping throughout the growing season resulting in at least three collections per year (1995-2001). Sampling was haphazardly distributed over the extent of the plots. All samples were collected within a $48 \mathrm{~h}$ period. Samples were dried at $68-70{ }^{\circ} \mathrm{C}$. The samples were brought to Florida International University, re-dried and ground using a Thomas Wily Mill (Arthur H. Thomas Co., Philadelphia, PA) or Wig-L-bug homogenizer (model LC-153, Crescent Dental Mfg, Inc). Samples were analyzed for Carbon $(\mathrm{C})$ and Nitrogen $(\mathrm{N})$ ratios using a Carlo Erba 1500-N CHN analyzer. A single modified Kjeldahl digestion was performed for nitrogen ( $\mathrm{N}$ ) and phosphorus $(P)$ determination. The resulting solutions were subsequently analyzed for Nitrogen colorimetrically using a Flow Solution IV Alpkem Colorimetric Analysis (EPA Method 351.2) and Phosphorus using a Spectro 
Ciros ICAP-Inductively Coupled Argon Plasma technique (EPA Method 200.7) at the University of Florida Institute of Food and Agricultural Science (IFAS) laboratory.

\section{Litter Decomposition}

Decomposition processes represent a major component of carbon and nutrient cycles within arctic ecosystems, and quantifying rates of litter mass and nutrient losses is critical for understanding nutrient cycling. Litter decomposition rates in response to the experimental treatments were evaluated using recentlysenesced dwarf birch (Betula nana) leaves collected near the study site in the fall of 1999. Only newly fallen leaves or leaves that easily detached from plants (with a well developed abscission layer) were collected. The plant material was dried to constant weight $\left(48 \mathrm{~h}, 70^{\circ} \mathrm{C}\right)$. In total, 120 bags were made from plastic screening $(8 \times 8 \mathrm{~cm})$ with $1.0 \mathrm{~mm}$ mesh size, and fused into small pouches with a hot iron. Each bag contained a preweighed amount of birch leaves (approximately $2 \mathrm{~g}$ dry weight). The entire sample of senescent birch leaves was well mixed prior to use to insure uniformity of all samples. Subsamples of the litter were taken for chemical analysis of initial litter quality.

On June 21,2000, litterbags containing Betula nana plant material were buried in each destructive plot of the two treatments and the control plots $(n=4)$ for determination of rates of decomposition. Approximately 1 year later, litterbags were retrieved during early season $(7 / 13 / 01)$, once depth of thaw was sufficient 
for removal, and late season $(8 / 31 / 01)$ prior to soil freezing. After samples were collected, roots growing into the bags were removed and the remaining litter was dried to constant weight and weighed to an accuracy of $0.1 \mathrm{mg}$. The samples were processed for nutrient analysis following the same procedures used for plant tissue material.

\section{Soil Solutions}

Lysimeters were used each year of the study to assess the soil solution nutrient concentrations. Collection of soil solutions was made at approximately the same time periods and frequency as plant tissue material. There were three collections in 1995, five in 1997, and four in 2000 and 2001. Collection of solution began as soon as depth of thaw was sufficient to insert the lysimeters into the soil. Once installed, the lysimeters were left in place for the length of the growing season. The lysimeters (Rhizon Soil Moisture Samplers) were constructed of a length of porous, chemically inert plastic $(2.3 \mathrm{~mm}$ o.d., $1.4 \mathrm{~mm}$ i.d., average pore diameter $0.1 \mu \mathrm{m}$ ) capped with nylon at one end and attached to a $5 \mathrm{~cm}$ polyethylene tube at the other end. Suction was provided by a pulled, $10 \mathrm{ml}$ syringe applied to the lysimeter $12 \mathrm{~h}$ prior to sample collection. The process was repeated until $10-15$ $\mathrm{ml}$ sample volume was collected. After collection, samples were acidified with 50 $\mu \mathrm{l}$ concentrated $\mathrm{HCl}$ and immediately frozen in order to prevent microbial activity. Samples were analyzed colorimetrically for $\mathrm{N}\left(\mathrm{NH}_{4}{ }^{+}-\mathrm{N}\right)$ with a Flow Solution IV (EPA Method 350.1) method, and $\mathrm{PO}_{4}{ }^{-}, \mathrm{K}^{+}$, and $\mathrm{Ca}^{+2}$ were analyzed with Spectro Ciros ICAP-Inductively Coupled Argon Plasma technique (EPA Method 
200.7) technique at University of Florida's Institute of Food and Agricultural Science laboratory.

\section{Exchangeable lons}

A large percentage of nutrients that plants and microbes assimilate from the soil solution are in ionic form, and nutrients in this form are interpreted as available or labile for uptake. Cations of interest include $\mathrm{NH}_{4}^{+}, \mathrm{K}^{+}, \mathrm{Mg}^{+2}, \mathrm{Ca}^{+2}$, and $\mathrm{Al}^{+3}$, and anions include $\mathrm{NO}_{3}{ }^{-}$and $\mathrm{PO}_{4}{ }^{3-}$. To measure bioavailability of ions in situ, I used anion (AEM) and cation (CEM)-exchange resin impregnated membranes (Ionics 1987). Ion-exchange membranes (IEMs) provide a well-defined planar ion-sink surface in direct contact with soil particles (Saunders 1964, Huang and Schoenau 1996). This configuration minimizes disturbance of the flow of water through soil and disturbances during placement and removal of membranes. The anion exchange membranes (AEM) and cation exchange membranes (CEM) used are polystyrene sheets with quarternary ammonium (AEM) or sulphonic acid (CEM) groups attached. Nitrate specific sensitive membranes are also available. The amount of nutrients sorbed on IEMs is not a quantitative measure of a pool size, but rather is an index of the ion supply (Saggar et al. 1990, Schoenau and Huang 1991a, Abrams and Jarrell 1992).

IEMs were installed in all 18 experimental nondestructive primary study plots during peak growing season (July 19) in 2000 and twice (July 24 and August 1) during the growing season in 2001. Both anion and cation membranes were cut 
into $5 \times 5 \mathrm{~cm}$ squares, a monofilament line was attached for easy retrieval, and rinsed with deionized water $\left(\mathrm{Dl}-\mathrm{H}_{2} \mathrm{O}\right)$. Before transport and installation, chloridesaturated AEMs were converted to bicarbonate form (Weih 1998). Three consecutive washes of $0.5 \mathrm{M} \mathrm{NaHCO}_{3}$ with alternating rinses of $\mathrm{DI}-\mathrm{H}_{2} \mathrm{O}$ were applied. This method is preferred for determining $P$ availability (Weih 1998). After transport to the field in Nalgene $30 \mathrm{ml}$ bottles, one AEM and one CEM were placed back-to-back and inserted into the soil at a slight angle with a serrated edged knife from a vertical slope $\left(20^{\circ} \pm 10^{\circ}\right)$, because this created better soil to membrane contact. After insertion, the soil opening was firmly pressed back to undisturbed state to ensure proper soil-membrane contact. In each plot, one pair of IEMS was placed in intertussock spaces and one pair in tussocks per plot. Membranes were not left in soil longer than $100 \mathrm{~h}$, because after this time the membranes no longer maintain a near-zero concentration of phosphate or nitrate at the surface (Weih 1998). Gilblin et al. (1994), using resin bags, noted that long deployment times gave lower estimates of nutrient availability than did a series of shorter deployments. Soil particles adhering to the surface were gently removed from membrane before rinsing with $\mathrm{DI}-\mathrm{H}_{2} \mathrm{O}$. AEMs and CEMs were placed in $25 \mathrm{ml}$ of $0.5 \mathrm{M} \mathrm{HCl}$ in Nalgene $30 \mathrm{ml}$ bottles and gently shaken for approximately $30 \mathrm{~h}$. The resulting solutions were subsequently analyzed for $\mathrm{PO}_{4}^{-}, \mathrm{K}^{+}, \mathrm{Mg}^{2+}, \mathrm{Mn}^{2+}, \mathrm{Fe}^{2+}$ and $\mathrm{NO}_{3}{ }^{-}$colorimetrically using a Flow Solution IV Alpkem Colorimetric Analysis (EPA Method 351.2) and Phosphorus with a Spectro Ciros ICAP-Inductively Coupled Argon Plasma technique (EPA Method 
200.7) at University of Florida's Institute of Food and Agricultural Science laboratory.

Statistical Analysis

The daily means of temperature $\left({ }^{\circ} \mathrm{C}\right)$, precipitation $(\mathrm{mm})$, wind speed $\left(\mathrm{ms}^{-1}\right)$, global radiation $\left(\mathrm{J} \mathrm{cm}^{-2}\right)$, and soil temperature $\left({ }^{\circ} \mathrm{C}\right)$ at $20 \mathrm{~cm}$ depth from May to September for the study years were tested for monthly and yearly differences using two-way analysis of variance (ANOVA). Variables were first checked for normality and heterogeneity of variances and transformed when necessary.

Plant tissue nutrients, Carbon to Nitrogen ratio $(\mathrm{C}: \mathrm{N})$ and phosphorus concentration (nutrient content in plant tissue material measured as percent of total mass), were analyzed for each species using a three-way randomized complete block ANOVA with three treatments, two, three or four years depending on component, and four or five collections depending on year of analysis. Soil nutrient solutions were analyzed in the same manner as the plant tissue nutrients.

Mass and nutrient changes of the litter decomposition bags were evaluated using one-way ANOVA. Soil exchangeable ions were analyzed for treatment, location, and collection effects with three-way ANOVA. 
Statistical analyses were carried out using SPSS 11.5 for Windows (SPSS 2002) software. Based on these findings, the results reported are the differences among treatments, years of study, and the collection during the year. In cases where significant differences were found, Fisher's least significance difference (LSD) post hoc tests were used to compare appropriate means. Tests were considered significant if $p<0.05$.

\section{Results}

\section{Microclimate properties}

I restricted all comparisons to weather data from 1 May to 30 September, which encompasses the entire growing season and shoulder seasons when tangible plant growth activity occurs.

Solar radiation peaked in May in all four years even though peak sun angles occur in late June. Cloud cover typically increased during the growing season, and combined with declining sun angles, was the basis for the decline in monthly solar radiation starting in June (Figure 3). Temperatures during the growing season were fairly consistent among years in June, July, and August, but considerable variation among years occurred in May and September (Figure 3). May was particularly variable among years. These monthly differences translated into significant differences in average growing season temperature. Mean daily air temperature $1.0 \mathrm{~m}$ above the surface ranged from 3.0 to $6.3^{\circ} \mathrm{C}$ with an average of $4.7^{\circ} \mathrm{C}$ for the $1995,1997,2000$, and 2001 growing seasons 
(Table 2). During these same years, the seasonal mean daily maximum temperature ranged from 7.7 to 10.9 and seasonal mean daily minimum ranged from -2.3 to $1.2^{\circ} \mathrm{C}$ (Table 2). Overall, 1997 was the warmest and 2000 was the coolest of the four study years. Soil temperature showed a similar pattern as that of air temperature (Figure 3). Precipitation was usually highest in July and August, but overall was highly variable among years (Figure 3).

Statistical analysis of microclimate data revealed differences for all recorded weather factors among years: air temperature, precipitation, wind speed, global radiation and soil temperature (Table 3). Air temperature, global radiation and soil temperature at $20 \mathrm{~cm}$ depth were also significantly different among years, and all daily averages except precipitation were significant for year $\mathrm{x}$ month interactions (Table 3).

Experimental manipulations resulted in an approximately $30 \%$ extension in the normal growing season length. The variability of spring weather conditions (snow load, temperature, and global solar radiation) affected the length of the early season manipulation. During the 1995 field season, warm spring temperatures led to $95 \%$ of the surface area of the control plots becoming snowfree by May $13^{\text {th }}$ whereas complete snow melt on the manipulation plots occurred by May $6^{\text {th }}$, thus providing only a one week early season difference between the manipulations and the controls. Over the course of the study $(1995,1997,2000$, and 2001), manipulated plots became snow-free on average by May $3^{\text {rd }}$ to May 
$7^{\text {th }}$. The control plots became snow free on May $13^{\text {th }}$, June $3^{\text {rd }}$, June $9^{\text {th }}$, and June $8^{\text {th }}$ for $1995,1997,2000$, and 2001 , respectively (Table 4). These extensions coupled with the late season extension from August $14^{\text {th }}$ to September $4^{\text {th }}$ at the end of the growing season accounted for a $28,49,60$, and 59 day extension of the growing season for each year, respectively.

\section{Plant Tissue $\mathrm{N}$ and C:N Ratios}

The overall patterns of carbon to nitrogen $(\mathrm{C}: \mathrm{N})$ ratios were similar among the treatments, with a general increasing trend of $\mathrm{C}: \mathrm{N}$ as the season progressed (see for example Betula nana, Figure 4). The increase in C: $\mathrm{N}$ ratio was largely due to decreases in nitrogen concentration rather than increases in carbon concentration. The differences in seasonal pattern among years was due in part to differences in timing of the snowmelt which resulted in different collection times for the plants. In 1997 and 2000, plant tissue material was collected prior to plants fully senescing, so the C:N ratios were not as high as years 1995 and 2001 when plant tissue was collected as senescence occurred (Figure 4).

The C:N of four of the seven species differed significantly in response to treatment (Table 5). There were significant main effects of collection and year for all seven species, $p<0.05$ (Table 5). Treatment $x$ year was significantly different for $L p$ and $V v i$. The year $\mathrm{x}$ collection interaction for $\mathrm{C}: \mathrm{N}$ ratio was significant for all species except $\mathrm{Cb}$ and $\mathrm{Pb}$ (Table 5). 


\section{Plant Tissue $\mathrm{P}$ content}

Phosphorus levels also decreased throughout the growing season for most species. Mean tissue phosphorus concentrations on the treatment plots were typically higher than those of the controls for most growth forms with the differences greatest early in the season (Figure 5). There were significant main effects of treatment for $B n$ and $L p$, time for $B n, S p, E v$, and $L p$, and year for all species, $p<0.05$ (Table 6 ). Mean phosphorus levels were significantly different across years for all species and collections except $C b, V v i$, and $P b$ (Table 6). Means were compared based on collections across years and were significantly different for all of the species (Table 6). Phosphorus concentration for treatment $x$ year was significantly different for $B n($ Table 6$)$. The year $x$ collection interaction was significant for phosphorus concentration in $B n, S p, C b$ and $L p$ (Table 6).

\section{Litter Decomposition}

Decomposition was very slow and the amount of mass loss was small $(<30 \%$ in 15 months, Table 7). With such slow rates, treatment differences were not apparent, although the tendency was for greatest loss on treatment plots. Litter weights were converted to percent dry mass remaining, which was then used to calculate a standard decomposition constant $(k)$ using the formula:

$$
X / X_{0}=e\left(^{-k t}\right)
$$

Where $X_{0}$ is the initial weight, $X$ is the final weight and $t=$ time since installation in days. Differences in $\mathrm{k}$ values among treatments were not significant, but again the tendency was for higher values on the treatment plots (Table 7). 
After fifteen months of incubation, $\mathrm{C}: \mathrm{N}$ ratios of both control and treatments were significantly higher compared to those of the control and treatments at the final collection. However, means compared across collections were not significantly different for treatments for any of the nutrient variables. For both experimental manipulations the tendency was for increased $\mathrm{N}$ and $\mathrm{P}$ concentrations, probably due to lower $C$ relative to that of the controls (Table 7 ).

\section{$\underline{\text { Soil Solutions }}$}

The seasonal patterns of ions from the soil solutions were distinct (Table 9, Figure 6). Potassium, $\mathrm{NH}_{4}-\mathrm{N}$, and $\mathrm{Ca}$ were higher at the end of the growing season than earlier (Table 9, Figure 6). Phosphorus and calcium concentrations were generally higher in the treatments than the controls. Although there were significant main effects of collection and year for $\mathrm{P}, \mathrm{K}, \mathrm{NH}_{4}$ and $\mathrm{Ca}$ for nutrient concentration $(p<0.05)$, the main effect for treatment was not significant (Table 8). Mean nutrient concentration levels were significantly different across collection for all elements except $\mathrm{Ca}$ (Table 8). Nutrient concentrations for treatment $x$ collection and treatment $x$ year were not significantly different for any of the elements (Table 8). The year $\mathrm{x}$ collection interaction was significant for all elements except $\mathrm{Ca}$ (Table 8). There was a significant three-way interaction for treatment $x$ year $x$ collection for $\mathrm{NH}_{4}$ (Table 8). 


\section{Exchangeable lons}

Exchangeable ions were sampled with ion exchange membranes once in 2000 and twice in 2001. The response of ion exchange membranes (IEMs) differed between tussock and intertussock locations. Manganese and iron concentrations were higher in intertussock locations (Figure 7). Potassium concentrations were higher in the tussock locations (Figure 7). Calcium and magnesium concentrations were variable for both location and treatments (Figure 7). There were significant main effects of treatment for $\mathrm{P}$ and $\mathrm{K}$, location (tussock versus intertussock) for $\mathrm{P}, \mathrm{K}$ and $\mathrm{Fe}$, type of membrane for $\mathrm{P}$, and collection (collection 1 or 2 in 2001) for $P$ for nutrient solution concentration, $p<0.05$ (Table 10). As expected, values for the heated and extended season plots were greater than those of the controls for both $\mathrm{P}$ and $\mathrm{K}$ in both years, with the exception of lower $\mathrm{K}$ on the heated plots than on the controls in 2001 (Table 11).

Interaction effects were significant for mean nutrient solution concentration levels across treatment $x$ location (Table 10). Means were compared based on collection frequencies between types and collections for 2001 only and were significantly different for $P$ (Tables 10 and 11). Treatment $x$ location and location $x$ type were also significantly different for $P$ (Table 10). 


\section{Discussion}

\section{Treatments and microclimate}

The treatments used in this study produced relatively small changes in the physical environment. Although the treatments lengthened the growing season approximately $30 \%$ on the study plots, about half of that was at the end of the growing season when plants are senescing in response to shortening daylengths (Shaver and Kummerow 1992, Oberbauer et al. 1998). The early season extension of approximately of 2-3 weeks is well within the range of variability of the natural timing of snowmelt at this site (Table 4, Hobbie et al. 2002).

Nevertheless, important effects on microclimate occurred in response to the snow removal treatment. Peak radiation at the site occurs in May; snow removal effectively shifts the growing season in the direction of higher solar inputs. Higher solar inputs over a longer period increase soil temperatures leading to increased depth of thaw. Soil temperatures at $5 \mathrm{~cm}$ on the snow removal treatments average about $1^{\circ} \mathrm{C}$ warmer than temperatures in the controls (Oberbauer et al. 1998). The snow-removal plus soil warming treatment increases soil temperature about $2^{\circ} \mathrm{C}$ (Oberbauer et al. 1998). A consequence of increased thaw depth is a lowering of the level of water perched above the frozen soil, decreasing soil moisture in the upper soil layers.

These microclimate changes have led to notable ecosystem effects. Bud break and green up occur earlier on the snow removal plots (Oberbauer et al. 1998, 
Pop et al. 2000). Green biomass at peak season increases as indicated by increased Normalized Difference Vegetative Index (NDVI) and leaf area index (LAI, Oberbauer et al.1998; Parker 2003). As a result of the increased biomass, ecosystem gross primary production increases (Oberbauer et al. 1998; Parker 2003).

The effect size of these treatments is strongly determined by the variability among years in terms of snow load, timing of snowmelt, cold temperatures in early season, and timing of the arrival of snow and cold temperatures-frost freeze events near the end of the season. Consequently, differences in plant and soil nutrients among the treatments must be interpreted within the context of this variability (Figure 4).

\section{Plant Nutrient Response}

Nutrient responses were relatively moderate among treatments and species, an expected finding given the mild treatment effects on the physical environment (McGraw 1987). These modest responses may also be attributed to the adaptation of tundra plants to chronically low nutrient environments, where having a high uptake capacity or growth rate is no advantage (Chapin 1980). Tundra plants are adapted to a wide range of seasonal and interannual climatic variation. Starr et al. (2000) in a detailed study of the forb, Polygonum bistorta, found no effect of the same snow removal treatments on leaf tissue nutrients. 
When nutrient availability is increased, leaf tissue nutrients may respond in two ways: 1) the concentration of nutrients may increase, increasing the physiological activity of that tissue, or 2) the concentration of nutrients in leaves may remain the same, but the amount of tissue produced increases. Some combination of the two is possible, which likely occurred in this study, where biomass clearly increased with relatively small changes in tissue concentrations.

Evaluation of plant responses to changes in nutrient availability is also complicated in the Arctic by carryover and lag effects from previous years due to adaptations to the short growing season. Leaf and flower primordia for a given year's growth are typically preformed the previous year. Consequently, a plant may not be able to respond to additional nutrients by increasing growth the year that they become available. Bowman and Conant (1994), working at Niwot Ridge, Colorado, showed that in response to fertilization a deciduous alpine tundra species had higher leaf tissue nutrients concentrations in the first year (when the number of leaves was predetermined) than the following years when leaf tissue concentrations fell back to original levels, but leaf production was greatly increased.

Superimposed on the plant responses and their lags are the differences in treatment strength as a result of the year-to-year seasonal temperature variation. The interannual variability also affected the tissue concentrations through its effect on plant phenology. Sampling was initiated based on when snow-melt 
occurred. Consequently, samples were not taken at the exact same time of year, and because of interannual temperature differences and their effects on rates of phenological change, samples were not necessarily at the same phenological stage at sampling each year. This difference explains the large variation in C:N ratios at the end of the season because in some years senescence was more advanced than in others at the time of collection. The tissue nutrients for the different growth forms were most strongly influenced by collection (time of season), then by year, and lastly by treatment.

\section{Litter decomposition}

Decomposition was slow $(<30 \%)$ during the fifteen months. Low soil temperature may have contributed to the low rate; years 2000 and 2001 were the coldest years (see averages in Table 2) of the study. Drying of soil surface may also have lowered the rate of decomposition on the treatment plots. Liski et al. (2003) were able to explain the decomposition rates of various litter types tested in a range of environments over large geographical using a simple model based on temperature and drought effects.

The tissue from birch leaves is relatively recalcitrant and requires a long incubation period to break down (Hobbie 1996). At the rates found in this study, it would have taken 6 y for $50 \%$ of the litter to decompose. Mary et al. (1996) have shown that for incubations carried out at low mineral $\mathrm{N}$ concentrations, the 
decomposition rate of plant residues is decreased but not stopped. The immobilization intensity, expressed per unit of mineralized $\mathrm{C}$, is reduced and $\mathrm{N}$ remineralization is delayed. Nitrogen availability in soil can therefore strongly modify the mineralization-immobilization turnover kinetics by a feed-back effect (Mary et al. 1996). The trend observed in my study was indicative of increased decomposition with treatments. Given more time, the trend is likely to show significant differences among the treatments, although the drying effect of treatments on decomposition may dampen the response.

\section{$\underline{\text { Soil solutions }}$}

No significant differences in soil solution nutrients were found among treatments in this study. This finding suggests a strong competition of roots with microbes and consequently, maintenance of soil solution nutrients at very low concentrations. An intriguing result was the increase of $\mathrm{NH}_{4}$ across years. However, it is unclear if this is an artifact of the sampling methodology or a real phenomenon. Likewise, there was a higher concentration of $\mathrm{NH}_{4}$ in 1997. However, there was a late collection in September that was not conducted the other years in the study that may have skewed the values higher. Otherwise, we see a general decreasing trend in nutrient concentration throughout the season. I should also note that uptake of organic nitrogen components have been shown to be an important component of nitrogen balance of tundra plants (Kielland 1994; Chapin 1995), but were not addressed in this study. However, these 
components would have likely responded similarly to the treatments as the inorganic forms of nitrogen.

\section{lon exchange membranes}

Ion exchange resins provide a more realistic estimate of what is bioavailable to the plants than soil solutions. The exchange membranes did indicate significant treatment effects for phosphorus and potassium. Giblin et al. (1994) observed that landscape differences in $\mathrm{N}$ vs. $\mathrm{P}$ availability ascertained from resins corresponded well with N/P ratios in soils and soil solutions and with results from factorial fertilizer experiments. Seasonal patterns of nutrient availability determined by resins were also consistent with plant uptake data (Giblin et al. 1994).

Where the membranes were located in my study also had a significant effect on the results. Tussock locations were higher in concentrations for $\mathrm{P}, \mathrm{K}$, and $\mathrm{Mg}$. This finding has important implications for nutrient partitioning among vascular species. Tussocks are occupied predominantly by Eriophorum vaginatum, which send annual roots vertically to exploit decomposing tissue. Other species largely are only able to exploit intertussock areas.

Nutrient dynamics in response to snow removal and soil warming All of the available evidence suggests that snow removal and soil warming increases the nutrients available for plants. These plots have undergone 
community changes and species abundance shifts, as well as exhibiting higher NDVI, LAI and gross primary productivity (Oberbauer et al. 1998; Parker 2003, Walker et al, unpublished data). My results support these observations and point to the overall mechanism behind them. I found higher $\mathrm{N}$ and $\mathrm{P}$ concentrations in several of the species in response to the experimental treatments. Given the higher nutrient concentrations and higher leaf area production, there is a substantial elevation of aboveground nutrient pools in treatment plots. Decomposition rates tend to be faster on the treatment plots. As more nutrient rich leaves from treatments decompose, there may be further increases in cycling rates. Soil solutions tended to be higher on treatment plots, and ion exchange membranes revealed significantly higher nutrient availability in response to snow removal. These results point to faster nutrient cycling in response to the snow removal and warming treatments.

My objectives were to evaluate the effects of season extension and soil warming, on nutrient availability within tussock tundra. My results clearly showed that nutrient availability in the system increased. However, a larger issue is whether this increase is sustainable or a transient phenomenon that is a result of lags in the system on its way to a new steady-state. Changes in primary production depend mainly upon the response of soil microbial decomposer activity to changes in soil temperature, moisture and plant litter quality (Callaghan and Jonasson 1995b). Assumptions that climate warming will lead to warmer soils 
and increased nutrient availability to sustain higher productivity are uncertain as greater biomass may lead to reduced soil temperatures through insulation effects, and additional nutrients released may be immobilized by soil microorganisms (Callaghan and Jonasson 1995b).

Arctic ecosystems have limited productivity due to low air and soil temperatures (Jonasson and Shaver 1999). Inorganic nutrient pools are small, limiting plant growth (Jonasson and Shaver 1999). Nutrient inputs from external sources are typically minimal, and pools in the vegetation also are small (Jonasson and Shaver 1999). In contrast, organically-bound nutrient stocks are large but mostly unavailable for plant uptake (Hobbie and Chapin 1998). If released slowly with increased decomposition, they could sustain increased growth for some time (Grogan and Chapin 2000). Arctic vegetation is very efficient in acquiring nutrients. By minimizing the seasonal nutrient losses and reducing the demand for nutrient uptake, tissue production and growth can continue for an extended period (Grogan and Chapin 2000).

Higher productivity is also sustainable with higher turnover rates (Grogan and Jonasson 2003). With higher productivity, more nutrients become available and leaf turnover increases with faster cycling of nutrients. In this ecosystem, more than $90 \%$ of the nitrogen and phosphorus absorbed by plants each year comes from the recycling of nutrients that were returned from vegetation to soils the previous year (Vitousek 1982). Tissue senescence is the major mechanism of 
nutrient loss from arctic vascular species. All else being equivalent, a reduction in tissue turnover causes a corresponding reduction in the turnover of the associated tissue nutrients. Plants compensate by reducing senescence loss of nutrients predominantly by reducing tissue turnover (Gifford et al. 2000). Tissue turnover is strongly reduced in low-resource environments such as the Arctic (Chapin et al. 1993). Low tissue turnover is probably the single most important adaptation for nutrient retention within this low-nutrient habitat (Gifford et al. 2000).

I did not address retranslocation of nutrients, but changes in retranslocation could accelerate nutrient cycling (Shaver and Laundre 1997). Nutrient resorption plays a crucial, but not completely understood, role in nutrient retention by plants. On average, plants in the Arctic resorb about half of their nitrogen, phosphorus and potassium from leaves before leaves are shed at senescence, so nutrient resorption is quantitatively important to plant nutrient budgets (Tolvanen and Henry 2001). Under field conditions, nutrient resorption may be influenced by so many factors that no single environmental factor has been identified as the primary control (Eckstein et al. 1999). Alternatively, nutrient resorption may be such an important trait that it is equally expressed in all arctic vascular plants.

Turnover times of the bulk soil organic matter in the Arctic can range from a few decades in the most productive systems to several centuries in the most nutrientdeficient ecosystem types (Jonasson and Shaver 1999). Decomposition rates of 
the soils are controlled by the varying environmental conditions (temperature, snow load, and soil-moisture) and nutrients can be strongly immobilized within the soil-microbial ecosystem compartment if the soil is nutrient poor (Zepp et al. 2003). The composition of the vegetation regulates the turnover of plants and plant nutrients but plays a less important role for the function of the entire plantsoil system (Jonasson and Shaver 1999). Characteristics of nutrient cycling at the larger scale level are less important for the function of the overall soil-plant system and characteristics of the plants in general (such as nutrient resorption, tissue type, and leaf longevity, etc.). These processes reflect the function of the system rather than play a major role in regulating ecosystem function (Jonasson and Shaver 1999).

The primary effects of my experimental treatments were warmer soils and deeper thaw depth, both of which increased nutrient availability for plants. Greater thaw depth both increases volume of soil available for rooting and lowers the water table thereby increasing the aerated zone in the soil. However, warmer soils may increase evaporation and lower soil moisture at the surface, a result that would tend to reduce decomposition rates (Hobbie 1996). The consequences of this drying may partially counteract the warming effects on a long-term basis.

Increased season length is only one of several possible scenarios for arcticregion season length predicted by GCMs. While the evidence is overwhelming that climate is warming in Alaska (Rabus and Echelmeyer 2002; Walker et al. 
2003), 3 of the last 4 y at the study site have had very late snowmelt, providing a shorter than normal growing season. Climate variability among the study years was very large. Virtually, all nutrient parameters differed significantly among years with significant interactions with collection date, suggesting that interannual variability in weather is driving many of the responses seen in this study. The season length signal of the treatments may have been overwhelmed by the noise of large interannual variability and its effects on seasonality.

Of all the components of environmental change (radiation inputs, $\mathrm{CO}_{2}$ concentration, nutrient availability, temperature, snow load, and soil-moisture), the ultimate driver for future change in arctic vegetation is likely to be increased nutrient availability (Gifford et al. 2000). Minor changes in precipitation, increases in radiation and increased atmospheric $\mathrm{CO}_{2}$ concentration alone will have little effect on arctic plants in the short term without an increase in nutrients to support additional growth. Any factors that change nutrient availability, such as temperature elevation or external nutrient inputs, however, will cause immediate plant-growth responses and alter nutrient cycling. In the case of increased nutrient and/or temperature, the effects on nutrient cycling may create positive feedbacks on plant biomass (Hobbie 1996). Thus, interactions among species, growth forms, resources, and climate may result in dramatic altercations in arctic communities and ecosystems on a long-term basis (Wolters et al. 2000). 
Table 1. The selected study species and their growth forms. The abbreviations used throughout the text are indicated below for each species.

\begin{tabular}{cccc}
\hline Forb & Graminoid & $\begin{array}{c}\text { Deciduous } \\
\text { shrub }\end{array}$ & Evergreen shrub \\
\hline $\begin{array}{c}\text { Polygonum } \\
\text { bistorta } \\
(\mathrm{Pb})\end{array}$ & $\begin{array}{c}\text { Eriophorum } \\
\text { vaginatum } \\
(\mathrm{Ev})\end{array}$ & $\begin{array}{c}\text { Betula nana } \\
(\mathrm{Bn})\end{array}$ & $\begin{array}{c}\text { Ledum palustre } \\
(\mathrm{Lp})\end{array}$ \\
& $\begin{array}{c}\text { Carex bigellowii } \\
(\mathrm{Cb})\end{array}$ & $\begin{array}{c}\text { Salix pulchra } \\
(\mathrm{Sp})\end{array}$ & $\begin{array}{c}\text { Vaccinium vitis- } \\
\text { idaea } \\
\text { (Vvi) }\end{array}$ \\
\hline
\end{tabular}


Table 2. Estimated means by Year for Daily Mean, Maximum, and Minimum Air Temperature $\left({ }^{\circ} \mathrm{C}\right)$ May - September 1995, 1997, 2000, and 2001.

\begin{tabular}{cccc}
\hline Year & $\begin{array}{c}\text { Mean air } \\
\text { temperature } \\
\left({ }^{\circ} \mathrm{C}\right)\end{array}$ & $\begin{array}{c}\text { Maximum air } \\
\text { temperature } \\
\left({ }^{\circ} \mathrm{C}\right)\end{array}$ & $\begin{array}{c}\text { Minimum air } \\
\text { temperature } \\
\left({ }^{\circ} \mathrm{C}\right)\end{array}$ \\
\hline 1995 & 5.9 & 10.4 & 1.2 \\
1997 & 6.3 & 10.9 & 1.3 \\
2000 & 3.0 & 7.7 & -2.3 \\
2001 & 3.7 & 7.7 & -2.0 \\
\hline
\end{tabular}


Table 3. Summary of microclimate properties for Toolik Field Station (May September) for years $1995,1997,2000$, and 2001 . Values are all daily averages and ${ }^{*}$ indicates significance at $p<0.05$.

\begin{tabular}{cccccc}
\hline Month 5-9 & $\begin{array}{c}\text { Air } \\
\text { Temper- } \\
\text { ature } \\
\text { Mean }{ }^{\circ} \mathrm{C}\end{array}$ & $\begin{array}{c}\text { Precipitation } \\
\text { Total } \mathrm{mm}\end{array}$ & $\begin{array}{c}\text { Wind } \\
\text { Speed } \\
\mathrm{m} / \mathrm{s}\end{array}$ & $\begin{array}{c}\text { Global } \\
\text { Radiation } \\
\mathrm{J} / \mathrm{cm}^{2}\end{array}$ & $\begin{array}{c}\text { Soil } \\
\text { Temperature } \\
{ }^{\circ} \mathrm{C} \text { at } 20 \mathrm{~cm}\end{array}$ \\
\hline Year & $*$ & $*$ & $*$ & $*$ & $*$ \\
Year x Month & $*$ & $*$ & $*$ & $*$ \\
\hline
\end{tabular}


Table 4. Dates of snowmelt and snow depth at the study site for 1995,1997 , 2000 , and 2001.

\begin{tabular}{ccc}
\hline Year & Date of Snowmelt & Snow Depth on May 2 \\
\hline 1995 & $5 / 13$ & 52.8 \\
1997 & $6 / 3$ & 65.4 \\
2000 & $6 / 9$ & 62.2 \\
2001 & $6 / 8$ & 65.0 \\
\hline
\end{tabular}


Table 5. Summary of ANOVA for plant tissue Carbon:Nitrogen ratio (Treatments C, E, $\mathrm{H}$ for 1995, 1997, 2000, and 2001). See Table 1 for species abbreviations.

\begin{tabular}{|c|c|c|c|c|c|c|c|}
\hline Main Effects & & & & Spe & ies & & \\
\hline Treatment & $\mathrm{Bn}$ & Sp & Ev & & & Vvi & \\
\hline Collection & $\mathrm{Bn}$ & $S p$ & Ev & $\mathrm{Cb}$ & $L p$ & Vvi & $\mathrm{Pb}$ \\
\hline Year & $\mathrm{Bn}$ & $S p$ & Ev & $\mathrm{Cb}$ & $L p$ & Vvi & $\mathrm{Pb}$ \\
\hline Treatment $x$ Collection & & & & & & & \\
\hline Treatment $x$ Year & & & & & Lp & Vvi & \\
\hline Year $\times$ Collection & $\mathrm{Bn}$ & Sp & Ev & & Lp & Vvi & \\
\hline Treatment $\times$ Year $\times$ Collecti & & & & & & & \\
\hline
\end{tabular}


Table 6. Summary of ANOVA for plant tissue Phosphorus (Treatments C, E, H for 1997, 2000, and 2001). See Table 1 for species abbreviations.

\begin{tabular}{|c|c|c|c|c|c|c|c|}
\hline Main Effects & \multicolumn{7}{|c|}{ Species } \\
\hline Treatment & $\mathrm{Bn}$ & & & & Lp & & \\
\hline Collection & $\mathrm{Bn}$ & $S p$ & Ev & & Lp & & \\
\hline Year & $\mathrm{Bn}$ & $S p$ & Ev & $\mathrm{Cb}$ & Lp & Vvi & $\mathrm{Pb}$ \\
\hline \multicolumn{8}{|l|}{ Treatment $x$ Collection } \\
\hline Treatment $x$ Year & $\mathrm{Bn}$ & & & & & & \\
\hline Year $\times$ Collection & $\mathrm{Bn}$ & $S p$ & & $\mathrm{Cb}$ & Lp & & \\
\hline Treatment $x$ Collection $x$ Year & & & & & & & \\
\hline
\end{tabular}


Table 7. Litter decomposition summary for final weight, decomposition constant (k), \% N, \% P, C:N and C:P ratios for 2000 and 2001. P-values are for tests of all treatments including initial. No significant effects were found for comparisons of control versus treatments alone.

\begin{tabular}{ccccccc}
\hline & $\begin{array}{c}\text { Final } \\
\text { Weight }\end{array}$ & $\mathbf{k}$ & $\% \mathbf{N}$ & $\% \mathbf{P}$ & $\begin{array}{c}\mathrm{C}: \mathbf{N} \\
\text { ratio }\end{array}$ & $\begin{array}{c}\text { C:P } \\
\text { ratio }\end{array}$ \\
\hline Initial & $\sim 2.000$ & & 0.91 & 0.200 & 62.50 & 249.09 \\
C & 1.539 & $7.77 \times 10^{-4}$ & 1.13 & 0.244 & 49.61 & 207.69 \\
E & 1.430 & $9.31 \times 10^{-4}$ & 1.16 & 0.208 & 45.50 & 221.90 \\
H & 1.321 & $8.67 \times 10^{-4}$ & 1.20 & 0.229 & 45.78 & 219.09 \\
& & & & & & \\
p-value & & 0.166 & & & & \\
\hline
\end{tabular}


Table 8. Summary of ANOVA for soil solutions (Treatments C, E, H for 1995, 1997,2000 , and 2001). * indicates significance at $p<0.05$

\begin{tabular}{|c|c|c|c|}
\hline Main Effect & $\mathbf{P}$ & $\mathrm{K} \quad \mathrm{Ca}$ & $\mathrm{NH}_{4}$ \\
\hline \multicolumn{4}{|l|}{ Treatment } \\
\hline Collection & * & * & * \\
\hline Year & * & * & * \\
\hline \multicolumn{4}{|l|}{ Treatment $x$ Collection } \\
\hline \multicolumn{4}{|l|}{ Treatment $x$ Year } \\
\hline Year $\times$ Collection & * & * & * \\
\hline Treatment $x$ Year $x$ Collection & & & * \\
\hline
\end{tabular}


Table 9. Estimated mean concentrations $(\mathrm{mg} / \mathrm{L})$ of soil solution nutrients by collection and year for Phosphorus (P), Potassium (K), Ammonium $\left(\mathrm{NH}_{4}\right)$, and Calcium (Ca). Symbols: $n / a=$ not available, $n / m=$ not measurable

\begin{tabular}{|c|c|c|c|c|c|}
\hline Collection & Year & Mean $(P)$ & Mean (K) & $\begin{array}{l}\text { Mean } \\
\left(\mathrm{NH}_{4}\right)\end{array}$ & Mean (Ca) \\
\hline 1 & $\begin{array}{l}1995 \\
1997 \\
2000 \\
2001\end{array}$ & $\begin{array}{l}0.078 \\
0.072 \\
0.080 \\
0.011\end{array}$ & $\begin{array}{l}0.693 \\
0.872 \\
0.574 \\
0.041\end{array}$ & $\begin{array}{l}0.110 \\
0.150 \\
0.228 \\
0.254\end{array}$ & $\begin{array}{l}1.459 \\
1.672 \\
1.562 \\
1.470\end{array}$ \\
\hline 2 & $\begin{array}{l}1995 \\
1997 \\
2000 \\
2001\end{array}$ & $\begin{array}{l}0.099 \\
0.061 \\
0.027 \\
0.006\end{array}$ & $\begin{array}{l}0.678 \\
0.497 \\
0.721 \\
0.091\end{array}$ & $\begin{array}{l}0.072 \\
0.028 \\
0.152 \\
0.213\end{array}$ & $\begin{array}{l}1.884 \\
1.407 \\
1.946 \\
1.897\end{array}$ \\
\hline 3 & $\begin{array}{l}1995 \\
1997 \\
2000 \\
2001\end{array}$ & $\begin{array}{l}\mathrm{n} / \mathrm{m} \\
0.012 \\
0.015 \\
0.039\end{array}$ & $\begin{array}{l}0.568 \\
0.617 \\
0.898 \\
0.697\end{array}$ & $\begin{array}{l}0.034 \\
0.117 \\
0.193 \\
0.155\end{array}$ & $\begin{array}{l}1.436 \\
1.444 \\
2.056 \\
1.425\end{array}$ \\
\hline 4 & $\begin{array}{l}1995 \\
1997 \\
2000 \\
2001\end{array}$ & $\begin{array}{l}\mathrm{n} / \mathrm{a} \\
0.016 \\
0.017 \\
\mathrm{n} / \mathrm{m}\end{array}$ & $\begin{array}{l}\mathrm{n} / \mathrm{a} \\
0.538 \\
0.570 \\
1.219\end{array}$ & $\begin{array}{l}\mathrm{n} / \mathrm{a} \\
0.056 \\
0.183 \\
0.208\end{array}$ & $\begin{array}{l}\mathrm{n} / \mathrm{a} \\
1.368 \\
2.012 \\
1.444\end{array}$ \\
\hline
\end{tabular}


Table 10. Summary of ANOVA for labile ions from ion exchange membrane results (Treatments C, E, H for 2000 and 2001). Only one collection was made in 2000; italicized effects indicate those effects that were only relevant to tests for 2001.

\begin{tabular}{|c|c|c|c|}
\hline \multirow{2}{*}{$\begin{array}{l}\text { Main Effects } \\
\text { Year }\end{array}$} & \multicolumn{3}{|c|}{ Ions (P, K, Ca, Mg, Mn, $\left.\mathrm{Fe}, \mathrm{NO}_{3}\right)$} \\
\hline & 2000 & 20 & \\
\hline Treatment & $\mathrm{K}$ & $\mathrm{P}$ & \\
\hline Location & $\mathrm{K}$ & $P$ & $\mathrm{Fe}$ \\
\hline Collection & & $P$ & \\
\hline Treatment $x$ Location & $\mathrm{Mn}$ & & \\
\hline \multicolumn{4}{|l|}{ Treatment $\times$ Collection } \\
\hline Location $\times$ Collection & & & \\
\hline
\end{tabular}


Table 11. Potassium $(\mathrm{K})$ and Phosphorus $(\mathrm{P})$ concentrations $(\mathrm{mg} / \mathrm{L})$ from ion exchange membranes for 2000 and 2001.

\begin{tabular}{lcccc}
\hline Treatment & \multicolumn{2}{c}{2000} & \multicolumn{2}{c}{$\begin{array}{c}\text { (Mean of two } \\
\text { collections) }\end{array}$} \\
\hline & $\mathbf{K}(\mathrm{mg} / \mathrm{L})$ & $\mathbf{P}(\mathrm{mg} / \mathrm{L})$ & $\mathbf{K}(\mathrm{mg} / \mathrm{L})$ & $\mathbf{P}(\mathrm{mg} / \mathrm{L})$ \\
\hline $\mathrm{C}$ & 24.02 & 0.207 & 16.29 & 0.718 \\
$\mathrm{E}$ & 43.57 & 0.390 & 17.77 & 1.083 \\
$\mathrm{H}$ & 32.86 & 0.268 & 14.24 & 0.896 \\
\hline
\end{tabular}




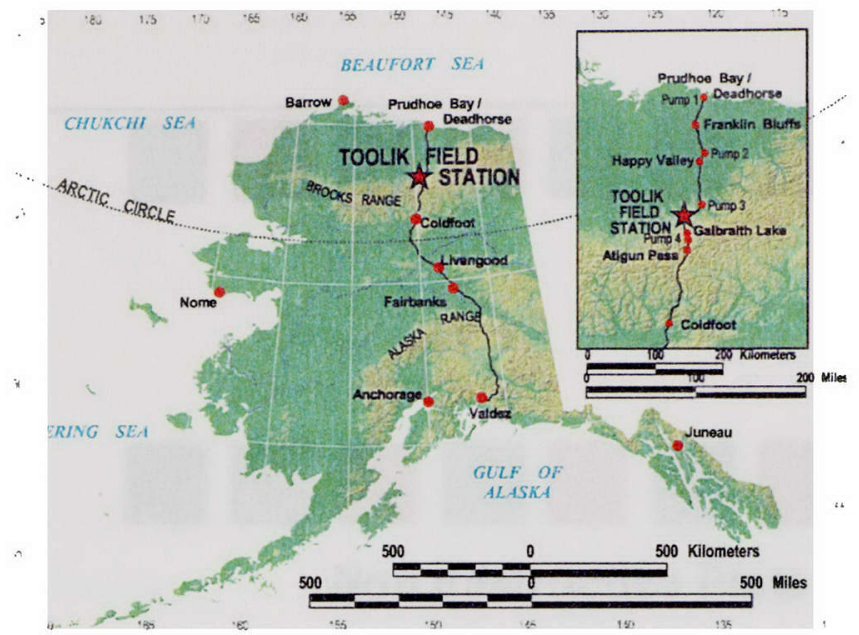

Figure 1. Alaska map with Toolik Field Station (TFS). (Map courtesy of Institute of Arctic Biology (IAB) at University of Alaska Fairbanks). 


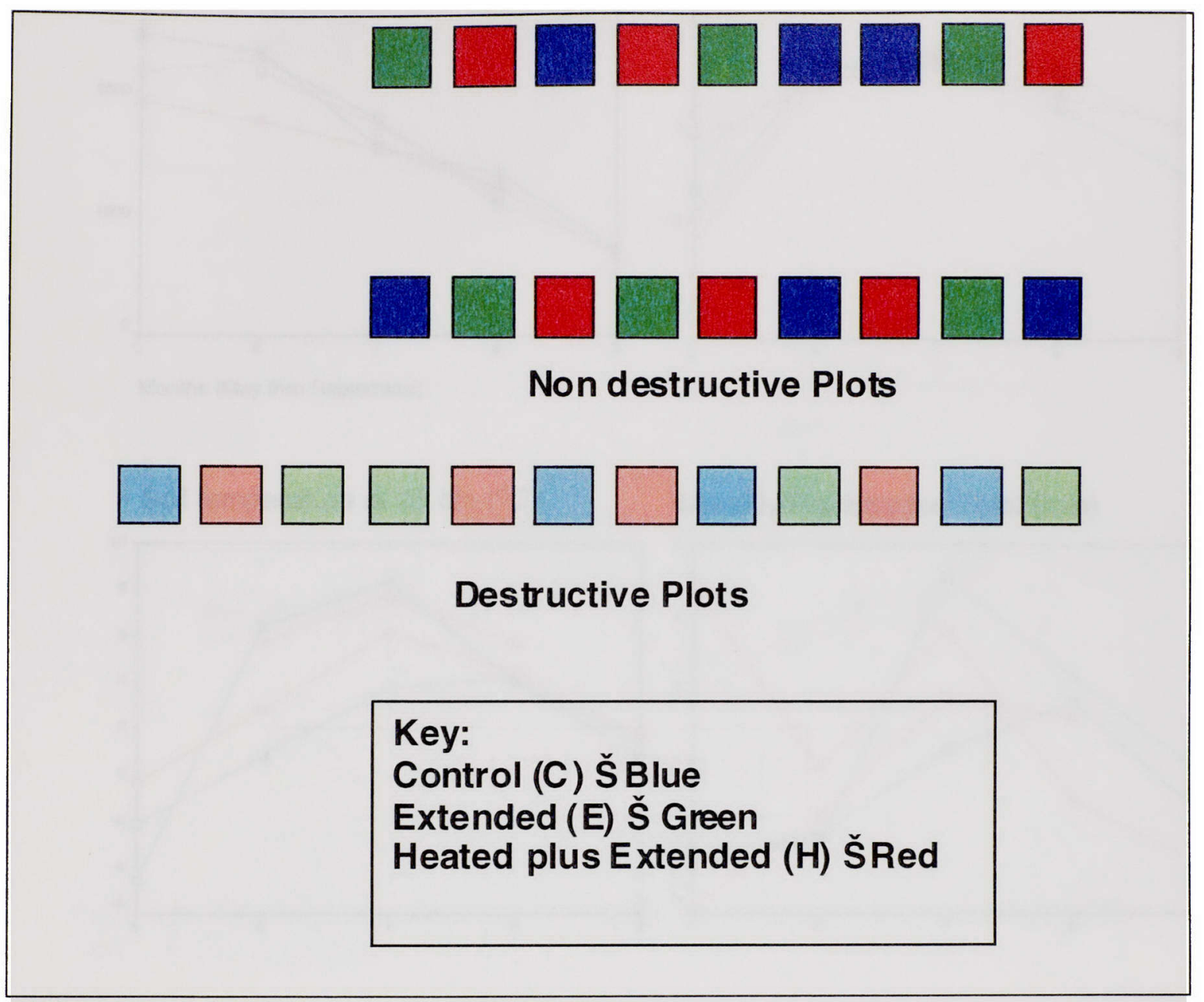

Figure 2. Plot layout of the study site. 
Monthly Global radiation $\left(\mathrm{J} / \mathrm{cm}^{2}\right)$

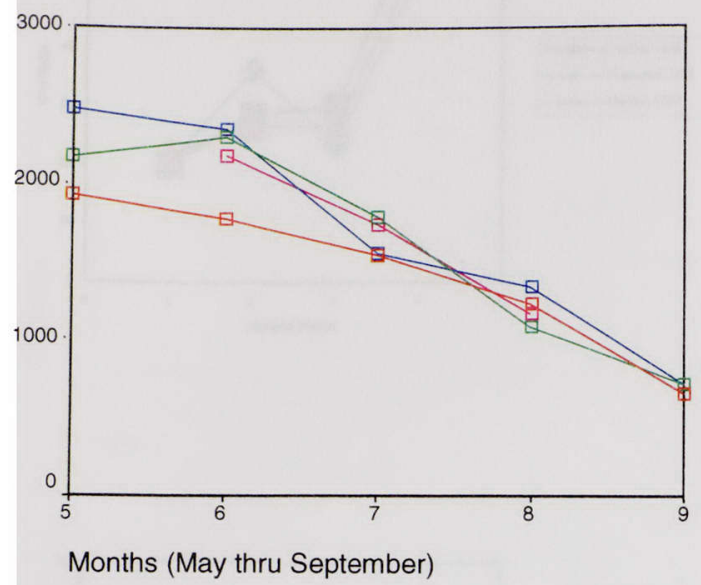

Soil temperature at $20 \mathrm{~cm}\left({ }^{\circ} \mathrm{C}\right)$
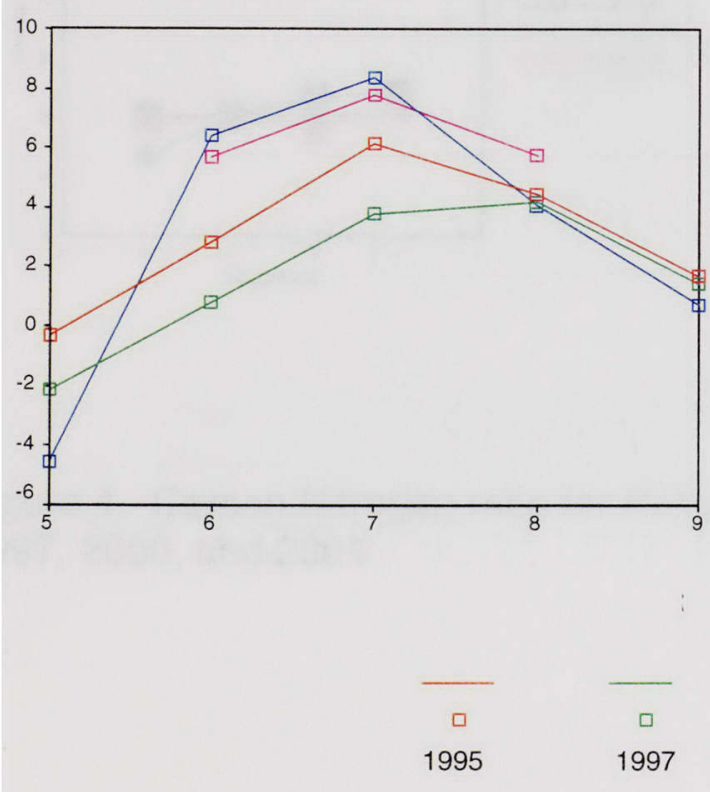

Monthly Air Temperature $\left({ }^{\circ} \mathrm{C}\right)$

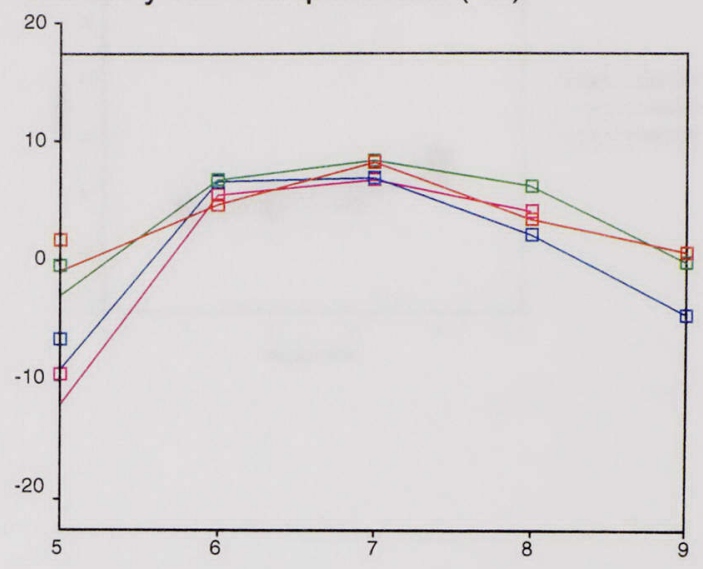

Monthly Precipitation Total $(\mathrm{mm})$
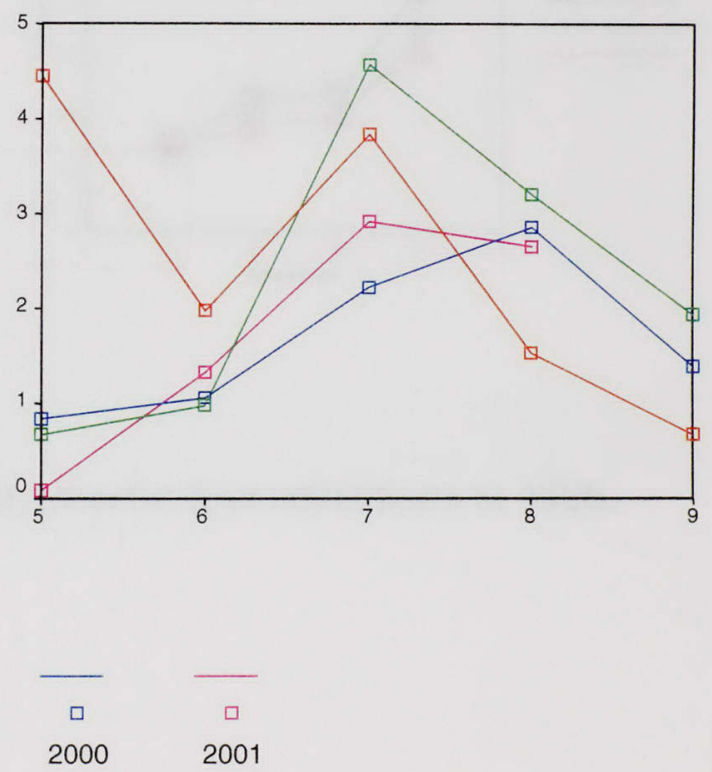

Figure 3. Means of daily global radiation, air temperature, soil temperature at 20 cm, and precipitation from May to September for 1995, 1997, 2000, and 2001. 

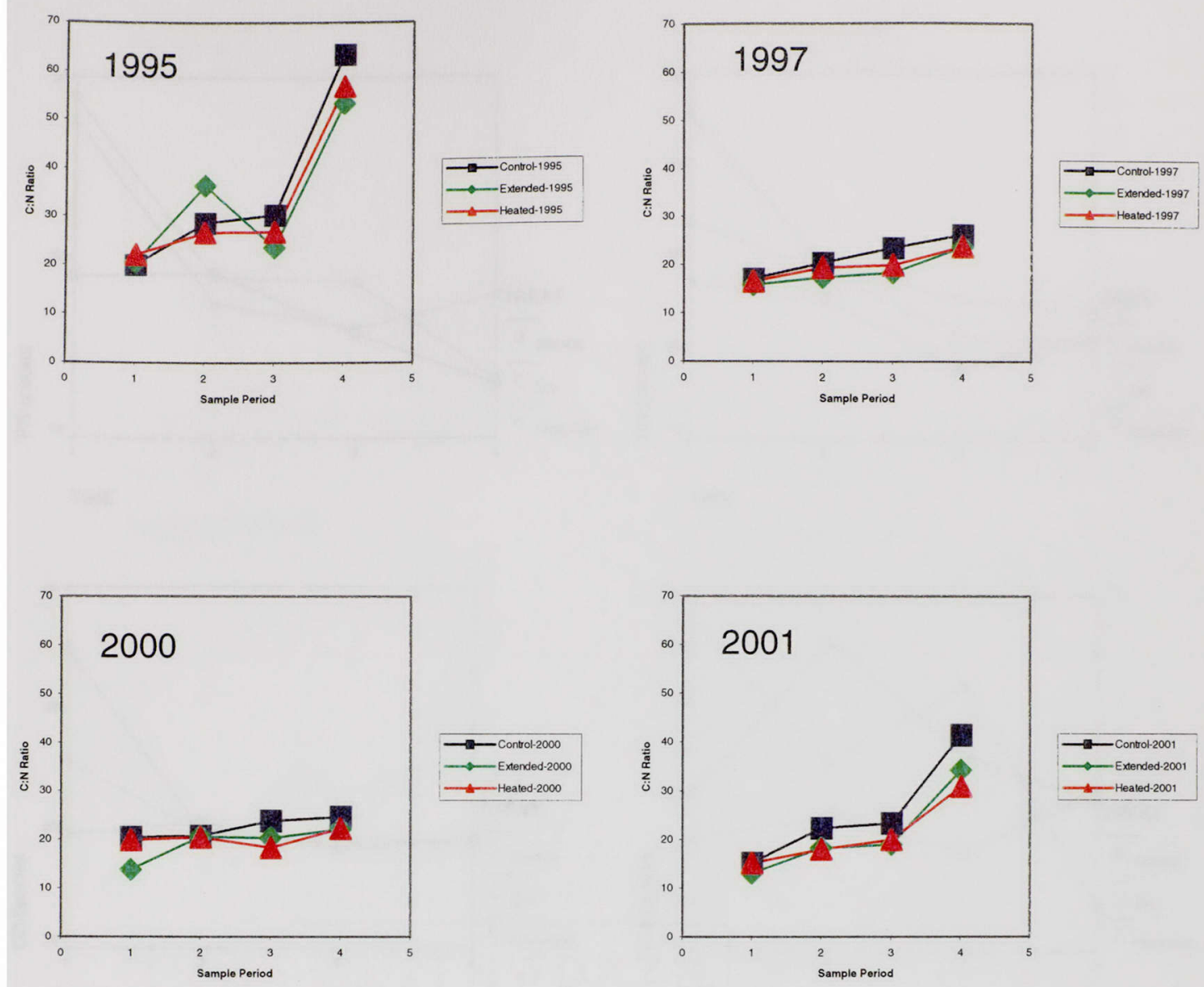

Figure 4. Carbon:Nitrogen ratio for Betula nana for four collections in 1995, 1997, 2000, and 2001. 




TIME

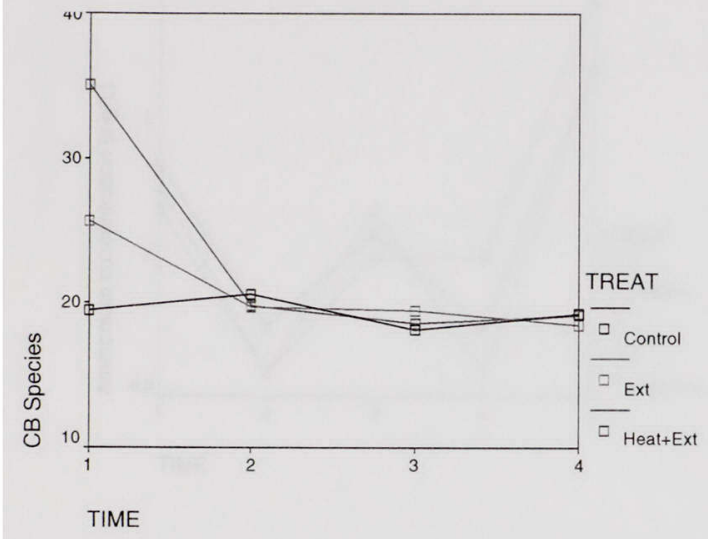

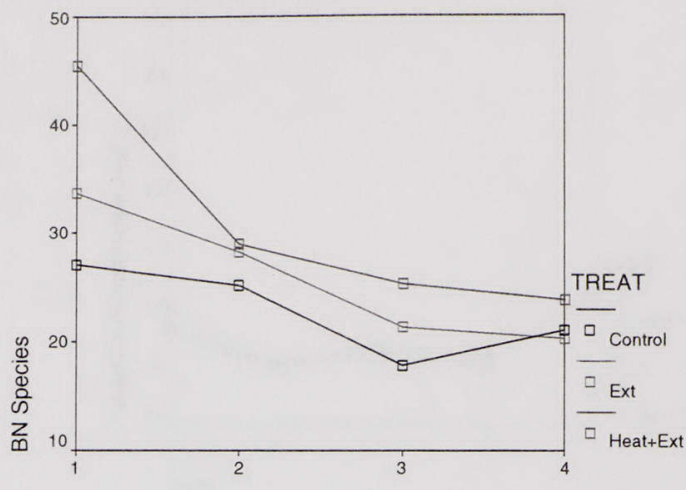

TIME

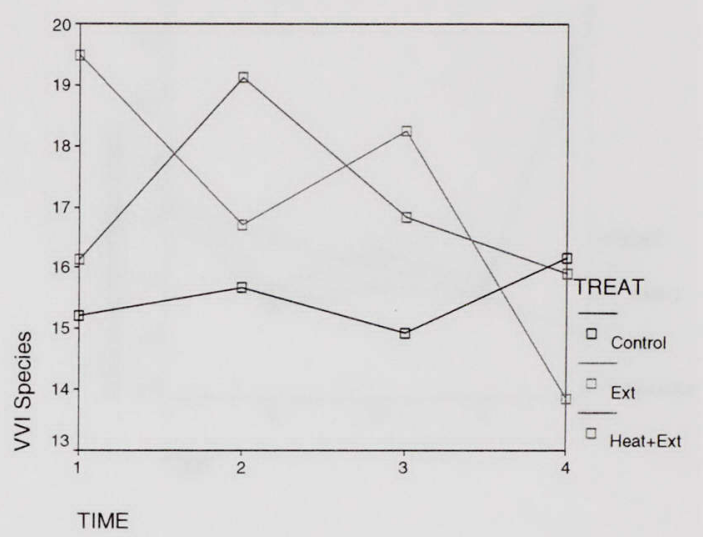

Figure 5. Mean concentrations $(\mathrm{mg} / \mathrm{g})$ of tissue phosphorus for four collections and three treatments for a representative species from each growth form. Means are averages of values from 1997, 2000, and 2001. 

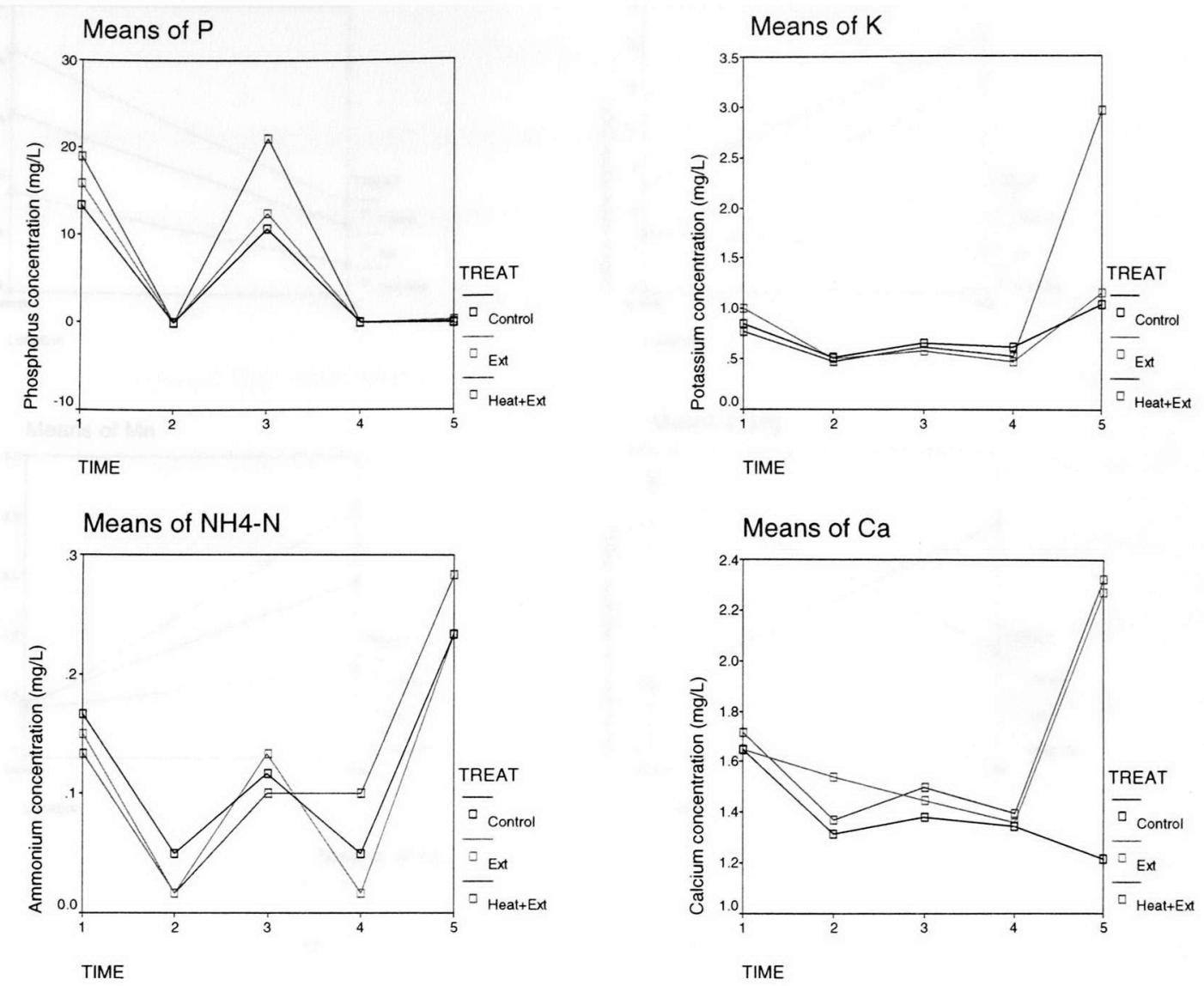

Figure 6. Mean concentrations of nutrients from soil solutions $(\mathrm{mg} / \mathrm{L})$ for four collections and the three treatments. Means are averages of values from 1995, 1997, 2000, and 2001. 

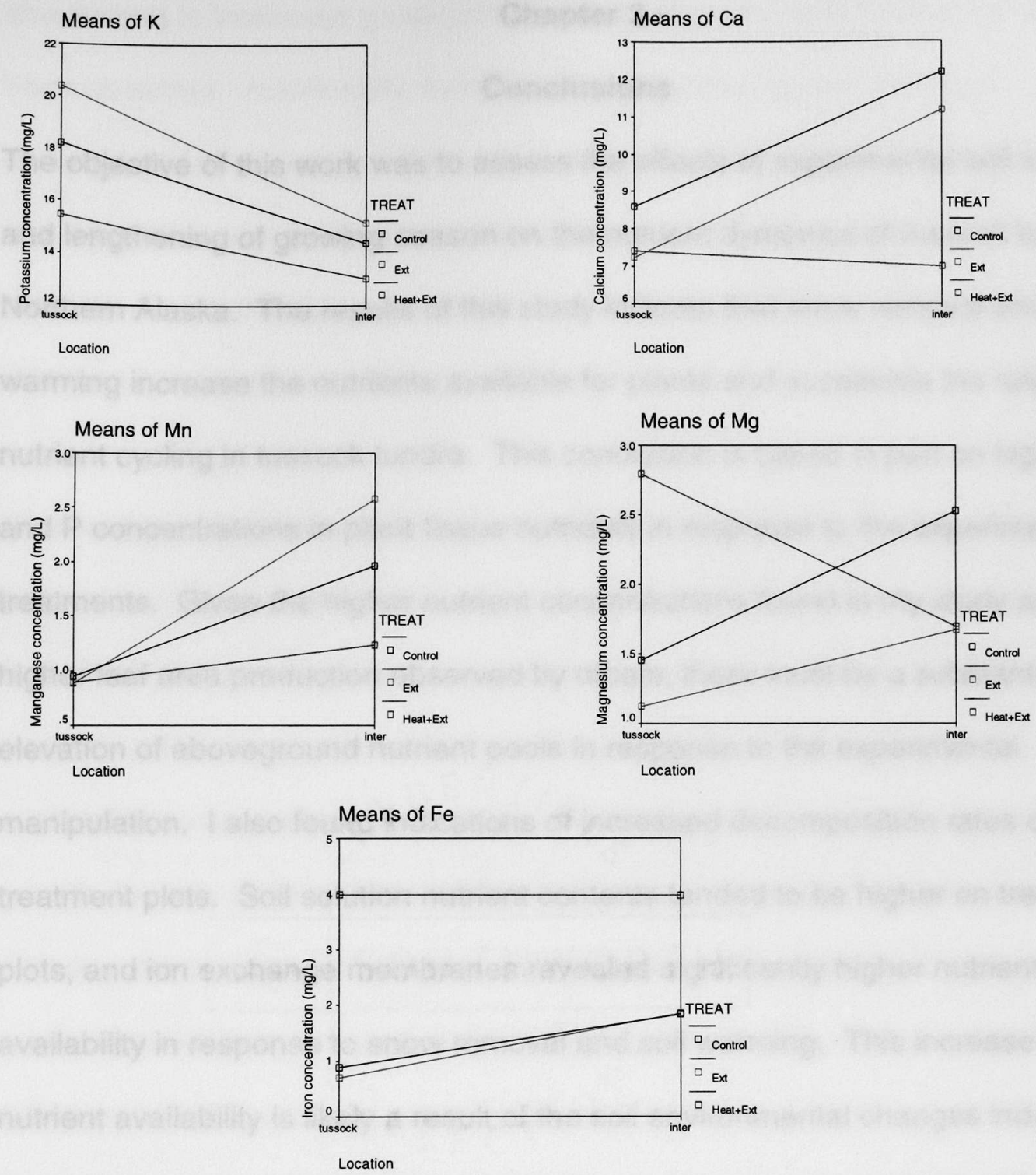

Figure 7. Mean concentrations of labile ions from ion exchange membranes (mg/L) for location (tussock and intertussock) collections. 


\section{Chapter 3.}

\section{Conclusions}

The objective of this work was to assess the effects of experimental soil warming and lengthening of growing season on the nutrient dynamics of tussock tundra in Northern Alaska. The results of this study indicate that snow removal and soil warming increase the nutrients available for plants and accelerate the rate of nutrient cycling in tussock tundra. This conclusion is based in part on higher $\mathrm{N}$ and $\mathrm{P}$ concentrations in plant tissue nutrients in response to the experimental treatments. Given the higher nutrient concentrations found in my study and higher leaf area production observed by others, there must be a substantial elevation of aboveground nutrient pools in response to the experimental manipulation. I also found indications of increased decomposition rates on the treatment plots. Soil solution nutrient contents tended to be higher on treatment plots, and ion exchange membranes revealed significantly higher nutrient availability in response to snow removal and soil warming. This increase in nutrient availability is likely a result of the soil environmental changes induced by snow removal, increased soil temperatures and increased soil depth of thaw.

These changes in soil environment presumably increased mineralization rates of limiting nutrients for plants as well as increased the soil volume available for root exploitation.

At the ecosystem level, the observed increase in nutrient availability has important implications for tundra carbon balance. Greater aboveground nutrients 
should lead to increased gross primary production, and such increases have been observed. Additionally, warmer soil environments and increased aboveground biomass should also increase ecosystem respiration, which also has been observed on the study plots. The overall carbon balance of these ecosystems will depend on the magnitude of these processes and how long changes in nutrient availability persist.

These treatment effects on nutrient dynamics, although significant in many instances, were superimposed on a background of large year-to-year variability, probably a result of large inter-annual differences in weather and timing of snowmelt. Plants of arctic environments are specifically adapted to low nutrient availability and posses traits that help reduce nutrient losses such as slow growth, low tissue concentrations, and low tissue turnover. These traits, while allowing plants to persist in highly variable environments, ultimately result in relatively subtle responses to environmental change such as those imposed by this experiment. 


\section{Literature Cited}

Abrams M.M. and Jarrell, W.M. 1992. Bioavailability index for phosphorus using ion exchange resin-impregnated membranes. Soil Soc. Am. J. 56:1532-1537.

Arft A.M., Walker, M.D., Gurevitch, J., Alatalo, J.M., Brete-Harte, M.S., Dale, M., Diemer, M., Gugerli, F., Henry, G.H.R., Jones, M.H., Hollister, R. D., Jonsdottir, I.S., Laine, K., Levesque, E., Marion, G.M., Molau, U., Mölgaard, P., Nordenahall, U., Raszhivin, V., Robinson, C.H., Starr, G., Stenstrom, A., Stenstrom, M., Totland, O., Turner, P.L., Walker, L.J., Webber, P.J., Welker, J.M., and Wookey, P.A. 1999. Responses of tundra plant species to experimental warming: meta-analysis of the International Tundra Experiment. Ecol. Monog. 69:491-511.

Bawa K.S. and Markham, H. 1995. Climate change and tropical forests. TREE 10:348349.

Berendse F. and Jonasson, S. 1992. Nutrient use and nutrient cycling in northern ecosystems. In: Chapin, F.S.III, Jefferies, R.L., Reynolds, J.F., Shaver, G.R., Svoboda, J. (Eds.), Arctic Ecosystems in a Changing Climate. An Ecophysiological Perspective. pp. 337-356. Academic Press, San Diego.

Bilbrough, C.J., Welker, J.M. and Bowman, W.D. 2000. Early-spring N uptake by snow covered plants: A comparison of arctic and alpine plant function under snowpack. Arct. Antarct. Alp. Res. 32:404-411.

Billings W.D., Luken, J.O., Mortensen, D.A., and Peterson, K.M. 1982. Arctic tundra: a source or sink for atmospheric carbon dioxide in a changing environment? Oecologia 53:7-11.

Billings W.D., Luken, J.O., Mortenson, D.A., and Peterson, K.M. 1983. Increasing atmospheric carbon dioxide: possible effects on arctic tundra. Oecologia 58:286289.

Bliss L.C. and Matveyeva, N.V. 1992. Circumpolar arctic vegetation. In: Chapin, F.S., Jefferies, R.L., Reynolds, J.F., Shaver, G.R., Svoboda, J. (Eds.) Arctic Ecosystems in a Changing Climate: An Ecophysiological Perspective. pp.59-89. Academic Press, San Diego.

Bowman W.D. 1992. Inputs and storage of nitrogen in winter snowpack in an alpine ecosystem. Arct. Alp. Res. 24:211-215.

Bowman W.D. and Conant, R.T. 1994. Shoot growth dynamics and photosynthetic response to increased nitrogen availability in the alpine willow Salix glauca. Oecologia 97:93-99. 
Brown S. 1993. Tropical forests and the global carbon cycle: the need for sustainable land-use patterns. Agric. Ecosyst. Envir. 46:31-44.

Callaghan T.V. and Jonasson, S. 1995a. Arctic terrestrial ecosystems and environmental change. Phil. Trans. Roy. Soc. Lond. 352:259-276.

Callaghan T.V. and Jonasson, S. 1995b. Implications for changes in arctic plant biodiversity from environmental manipulation experiments. In: Chapin, F.S.III, Korner, C. (eds), Arctic and Alpine Biodiversity: Patterns, Causes and Ecosystem Consequences. Ecol. Stud. 113, pp. 151-166. Springer, Berlin.

Callaghan T.V. and Jonasson, S. 1998. The Abisco Scientific Research Station: Future environments and horizons. AMBIO 27(4): 256-257.

Cattle H. and Crossley, J. 1995. Modeling of arctic climate change. Phil. Trans. R. Soc. Lond. A. 352:201-213.

Chapin F.S.III. 1980. The mineral nutrition of wild plants. Ann. Rev. Ecol. Syst. 11:233-260.

Chapin, F.S.III, Tieszen, L.L., Lewis, M., Miller, P.C., and McCown B.H. 1980. Control of tundra plant allocation patterns and growth. In: Brown J., Miller, P. Tieszen, L. and Bunnell F. (Eds.), An Arctic Ecosystem: The Coastal Tundra at Barrow, Alaska. pp. 140-185 . Dowden, Hutchinson and Ross, Stroudsburg.

Chapin F.S.III. 1995. New cog in the nitrogen cycle. Nature 377:199-200.

Chapin F. S., III, Johnson, D.A. and McKendrick, J.D. 1980a. Seasonal movement of nutrients in plants of differing growth form in an Alaskan tundra ecosystem: Implications for herbivory. J. Ecol. 68:189-209.

Chapin F.S.III. 1987. Environmental control over growth of tundra plants. Ecol. Bull. 38:69-76.

Chapin F.S.III, Autumn K., and Pugnaire, F. 1993. Evolution of suites of traits in response to environmental stress. Am. Nat. 142:S78-S92.

Chapin F.S.III, Shaver, G.R., Giblin, A.E. Nadelhoffer, K.J. and Laundre, J.A. 1995. Response of arctic tundra to experimental and observed changes in climate. Ecology 76:694-711.

Chapin F.S.III, Hobbie, S.E., Bret-Harte, M.S. and Bonan, G. 1995a. Causes and consequences of plant functional diversity in arctic ecosystems. In: Chapin F.S.III and Körner C. (Eds) Arctic and Alpine Biodiversity. pp. 225-237. Springer, Berlin. 
Chapin F.S.III, and Shaver, G.R. 1996. Physiological and growth responses of arctic plants to a field experiment simulating climate change. Ecology 77:822-840.

Chapin F.S.III, Walker, B.H, Hobbs, R.J., Hooper, D.U., Lawton, J.H., Sala, O.E., and Tilman, D. 1997. Biotic control over the functioning of ecosystems. Science 277:500-504.

Chapin F.S.III, McGuire, A.D., Randerson, J., Pielke, R., Baldocchi, D., Hobbie, S.E., Roulet, N., Eugster, W., Kasischke, E., Rastetter, E.B., Zimov, S.A., and Running, S.W. 2000. Arctic and boreal ecosystems of western North America as components of the climate system. Glob. Change Biol. 6 (suppl):211-223.

Cohen S.J. 1990. Bringing the global warming issue closer to home: The challenge of regional impact studies. Bull. Am. Meterol. Soc. 71:520-526.

Cubasch W. and Meehal, G.A. 2001. Projections of future climate change. In: Climate Change 2001 (PCC). pp. 525-582, Cambridge University Press, Cambridge.

Eckstein R.L., Karlsson, P.S., and Weih, M. 1999. Leaf life span and nutrient resorption as determinants of plant nutrient conservation in temperatearctic regions. New Phytol.143:177-189.

Eckstein R.L. and Karlsson, P.S. 2001. The effect of reproduction on nitrogen use-efficiency of three species of the carnivorous genus Pinguicula. $J$. Ecol. 89:798-806.

Flanagan P.W., and Veum, A.K. 1974. Relationships between respiration, weight loss and moisture in organic residues on tundra. In: Holding, A.J., Heal, O.W., MacLean, S.F., Jr., Flanagan, P.W. (Eds.), Decomposition of Organic Matter in Tundra. Tundra Biome Steering Committee, Stockholm. pp. 249-277.

Forbes B.C. 1995. Effects of surface disturbance on the movements of native and exotic plants under a changing climate. In: Callaghan, T.V., Oechel, W.C., Gilmanov, T., Molau, U. Maxwell, B. Tyson, M., Sveinbjornsson, B., Hoten, J.I. (Eds), Global Change and Arctic Terrestrial Ecosystems. pp. 209-219. European Commission, Luxembourg.

Giblin, A.E., Nadelhoffer, K.J., Shaver, G.R., Laundre, J.A. and McKerrow, A.J. 1991. Biogeochemical diversity along a riverside toposequence in arctic Alaska. Ecol. Monogr. 61:415-436. 
Giblin A.E., Laundre, J.A., Nadelhoffer, K.J., and Shaver, G.R. 1994. Measuring nutrients availability in arctic soils. Soil Sci. Soc. Amer. J. 47:1008-1014.

Gifford R.M., Barrett, D.J., and Lutze, J.L. 2000. The effects of elevated $\left[\mathrm{CO}_{2}\right]$ on the C:N and C:P mass ratios of plant tissues. Plant Soil. 224:1-14.

Gorsuch D.M. and Oberbauer, S.F. 2002 Effects of mid-season frost and elevated growing season temperature on stomatal conductance and specific xylem conductivity of the arctic shrub, Salix pulchra. Tree Physiol. 22:1027-1034.

Grogan P. and Chapin, F.S.III. 2000. Initial effects of experimental warming on above- and belowground components of net ecosystem $\mathrm{CO}_{2}$ exchange in arctic tundra. Oecologia. 125:512-520.

Grogan, P. and Jonasson, S. 2003. Controls on annual nitrogen cycling in the understory of a subarctic birch forest. Ecology. 84:202-218.

Haag, R.W. 1974. Nutrient limitations to plant production in two tundra communities. Can. J. Bot. 52:103-116.

Havström M., Callaghan, T.V., and Jonasson, S. 1993. Differential growth responses of Cassiope tetragona, an arctic dwarf-shrub, to environmental perturbations among three contrasting high-and sub-arctic sites. Oikos 66:389-402.

Heal O.W. and French, D.D. 1974. Decomposition of organic matter in tundra. In: Holding, A.J., Heal, O.W., MacLean, Jr. S.F. Flanagan, P.W. (Eds), Decomposition of Organic Matter in Tundra. pp. 279-309. Tundra Biome Steering Committee, Stockholm.

Henry G.H.R. and Molau, U. 1997. Tundra plants and climate change: the International Tundra Experiment (ITEX). Glob. Change Biol. 3:S1-S9.

Hobbie S.E. 1992. Effects of plant species on nutrient cycling. TREE 7:336-339

Hobbie S.E. 1996. Temperature and plant species control over litter decomposition in Alaskan tundra. Ecol. Monogr. 66:503-552.

Hobbie S.E. and Chapin, F.S.III. 1998. Response of tundra plant biomass, aboveground production, nitrogen, and $\mathrm{CO}_{2}$ flux to experimental warming. Ecology 79:1526-1544.

Hobbie S.E., Shevtsova, A., and Chapin, F.S.III. 1999. Plant responses to species removal and experimental warming in Alaskan tussock tundra. Oikos 84:417-434. 
Hobbie S.E., Nadelhoffer, K.J., and Högberg, P. 2002. A synthesis: The role of nutrients as constraints on carbon balances in boreal and arctic regions. Plant Soil. 242:163-170.

Huang W.Z. and Schoenau, J.J. 1996. Microsite assessment of forest soil nitrogen, phosphorus, and potassium supply rates in the field using ion exchange membranes. Commun. Soil. Sci. Plant Anal. 27:2895-2908.

Hultén E. 1968. Flora of Alaska and Neighboring Territories: a manual of the vascular plants. Stanford University Press. Stanford, CA.

Ionics, Inc. 1987. Properties and characteristics of anion and cation transfer membrane type AR 204, CR 67, \& AR 103. Bulletin AR 204.3-A. Ionics, Watertown, MA.

IPCC 2001. Summary for Policy Makers: The Third Assessment Report of Working Group I of the Intergovernmental Panel on Climate Change.

Jaeger, C.H., Monson, R.K., Fisk, M., and Schmidt, S. 1999. Seasonal partitioning of nitrogen by plants and soil microorganisms in an alpine ecosystem. Ecology 80:1883-1891.

Jefferies R.L., Svoboda, J., Henry, G. Railard, M., and Ruess, R. 1992. Tundra Grazing Systems and Climatic Change. In: Chapin, F.S.III, Jefferies, R.L., Reynolds, J.F., Shaver, G.R., and Svoboda, J. (Eds.), Arctic Ecosystems in a Changing Climate: An Ecophysiological Perspective. pp. 391-412. Academic Press, San Diego.

Jonasson S. 1982. Organic matter and phytomass on three north Swedish tundra sites, and some connections with adjacent tundra areas. Holarct. Ecol. 5:367-375.

Jonasson S. 1983. Nutrient content and dynamics in north Swedish shrub tundra areas. Holarct. Ecol. 6:295-304.

Jonasson S., and Chapin, F.S.III.1985. Significance of sequential leaf development for nutrient balance of the cotton sedge, Eriophorum vaginatum, L. Oecologia $67: 511-518$.

Jonasson S. 1992. Growth responses to fertilization and species removal in tundra related to community structure and clonality. Oikos 63, 420-429.

Jonasson S. 1995. Ecophysiological sensitivity of terrestrial vascular plants to climate change. In: Guisan, A., Holten, J.I., Spichiger, R., Tessier, L. (Eds.) Potential Ecological Impacts of Climate Change in the Alps and Fennoscandian Mountains. Ed. pp. 59-61. Conserv. Jard. Bot., Geneve. 
Jonasson S., and Michelsen, A. 1996. Nutrient cycling in subarctic and arctic ecosystems, with special reference to the Abisko and Torneträsk region. Ecol. Bull. 45:45-52.

Jonasson S. and Shaver, G.R. 1999. Within-stand nutrient cycling in arctic and boreal wetlands. Ecology 80:2139-2150.

Kane D.L., Hinzman, L.D., Woo, M-K., and Everett, K.R. 1992. Arctic hydrology and climate change In: Chapin, F.S.III, Jefferies, R.L., Reynolds, J.F., Shaver, G.R., and Svoboda, J. (Eds.), Arctic Ecosystems in a Changing Climate: an Ecophysiological Perspective. pp. 35-57. Academic Press, San Diego.

Keeling C.D., Whorf, T.P., Wahlen, M. and van der Plicht, J. 1995. Interannual extremes in the rate of rise of atmospheric carbon dioxide since 1980. Nature 375:666-670.

Kerr R.A. 1988. Report urges greenhouse action now. Science 243:23-24.

Kielland, K. 1994. Amino-acid absorption by arctic plants-implications for plant nutrition and nitrogen cycling. Ecology 75:2373-2383.

Liski J., Nissinen A., Erhard M., and Taskinen O. 2003. Climatic effects on litter decomposition from arctic tundra to tropical rainforest. Glob. Change Biol. 9:575-584.

Marion, G.M. 1996. Elemental mobility through small tundra watersheds. Arct. Alp. Res. 28:339-345.

Mary B., Recous, S., Darwis, D., and Robin, D. 1996. Interactions between decomposition of plant residues and nitrogen cycling in soil. Plant Soil 181:71-82.

Maxwell B. 1992. Arctic climate: Potential for change under global warming. In: Chapin, F.S.III, Jefferies, R.L., Reynolds, J.F., Shaver, G.R., Svoboda, J. (Eds.). Arctic Ecosystems in a Changing Climate: an Ecophysiological Perspective. pp. 11-34. Academic Press, San Diego.

Maxwell B. 1996. Recent climate patterns in the Arctic. In: Oechel, W.C., Callaghan, T., Gilmanov, T., Holten, J.I., Maxwell, B., Molau, U., Sveinbjornsson, B. (Eds.) Global Change and Arctic Terrestrial Ecosystems. pp. 21-46. Springer-Verlag, New York.

McGraw, J.B. 1987. Experimental ecology of Dryas octopetala ecotypes. V. Field photosynthesis of reciprocal transplants. Hol. Ecol. 10:308-311. 
McGuire A.D., Wirth C., Apps M., Beringer J., Clein J., Epstein H., Kicklighter D.W., Bhatti J., Chapin F.S., de Groot B., Efremov D., Eugster W., Fukuda M., Gower T., Hinzman L., Huntley B., Jia G.J., Kasischke E., Melillo J., Romanovsky V., Shvidenko A., Vaganov E., and Walker D. 2002 Environmental variation, vegetation distribution, carbon dynamics and water/energy exchange at high latitudes J. Veg. Sci. 13:301-314.

McKane R.B., Rastetter, E.B., Shaver, G.R., Nadelhoffer, K.J., Giblin, A.E. Laundre, J.A. and Chapin, F.S.III. 1997. Climatic effects on tundra carbon storage inferred from experimental data and a model. Ecology 78:11701187.

Oberbauer S.F., Starr, G., and Pop, E.W. 1998. Effects of extended growing season and soil warming on carbon dioxide and methane exchange of tussock tundra in Alaska. J Geophys. Res-Atmos 103:29075-29082

Oechel W.C., and Billings, W.D., 1992. Effects of global change on the carbon balance of arctic plants and ecosystems, In: F.S. Chapin III, R.L. Jefferies, J.F. Reynolds, G.R. Shaver and J. Svoboda (Eds.) Arctic Ecosystems in a Changing Climate: An Ecophysiological Perspective. pp. 139-168. Academic Press, San Diego.

Parker, I.C. 2003. Relating ecosystem $\mathrm{CO}_{2}$ exchange to spatial representations of the normalized difference vegetation index in the Arctic. M.S. thesis. Florida International University.

Parsons A.N., Welker, J.M., Wookey, P.A. Press, M.C., Callaghan, T.V., and Lee, J.A. 1994. Growth responses of four sub-arctic dwarf shrubs to simulated environmental change. J. Ecol. 82:307-318.

Pop E.W., Oberbauer, S.F., and Starr, G. 2000. Predicting vegetative bud break in two arctic deciduous shrub species, Salix pulchra and Betula nana. Oecologia 124:176-184.

Post W.M., Emanuel, W.R., Zinke, P.J., and Strangenberger, A.G. 1982. Soil carbon pools and world life zones. Nature 298:156-159.

Rabus B.T., and Echelmeyer, K.A. 2002. Increase of $10 \mathrm{~m}$ ice temperature: climate warming or glacier thinning? J. Glaciol. 48:279-286.

Rastetter E.B., McKane, R.B., Shaver, G.R., Nadelhoffer, K.J., and Giblin, A.E. 1996. Analysis of $\mathrm{CO}_{2}$, temperature and moisture effects on carbon storage in Alaskan arctic tundra using a general ecosystem model. In: Oechel, W.C., Callaghan, T.V., Gilmanov, T., Holten, J.I., Maxwell, B., Molau, U., Sveinbjörnsson, B. 
(Eds.), Global Change and Arctic Terrestrial Ecosystems. Ecological Studies series Vol. 124. Springer, New York.

Romanovsky V.E., and Osterkamp, T.E. 1997. Thawing of the active layer on the coastal plain of the Alaskan Arctic Permafrost Periglac 8:1-22.

Saggar S., Hedley, M.J., and White, R.E. 1990. A simplified resin membrane technique for extracting phosphorus from soils. Fertil. Res.24:173-180.

Sauders W.M.H. 1964. Extractions of soil phosphate by anion-exchange membranes. N.Z.J. Agr. Res. 7:427-431.

Schoenau J.J. and Huang, W.Z. 1991. Anion-exchange, membranes, water, and sodium bicarbonate extractions as soil test for phosphorus. Soil Sci. Plant Anal. 22:465-492.

Schimel D.S., Braswell, B.H., Holland, E.A., McKeown, R., Ojima, D.S. Painter, T., Parton, W.J, and Townsand, A.R. 1994. Climatic, edaphic, and biotic controls over storage and turnover of carbon in soils. Glob. Biogeo. Cycl. 8:279-293.

Serreze M.C. and Hurst, C.M. 2000. Representation of mean arctic precipitation from NCEP-NCAR and ERA reanalyses. J. Climate 13:182-201.

Serreze M.C., Walsh, J.E., Chapin, F.S.III, Osterkamp, T., Dyurgerov, M., Romanovsky, V., Oechel, W., Morison, F., Zhang,T., and Barry, R.G. 2000. Observational evidence of recent change in northern high-latitude environments. Clim. Change 46:159-207.

Shaver G.R., and Chapin, F.S.III. 1980. Responses to fertilization by various plant growth forms in an Alaskan tundra: nutrient accumulation and growth. Ecology 61:662-675.

Shaver G.R., and Chapin, F.S. III. 1986. Effect of fertilizer on production and biomass of tussock tundra, Alaska, U.S.A. Arct. Alp. Res. 18:261-268.

Shaver G.R. and Chapin, F.S.III. 1991. Production: biomass relationships and element recycling in contrasting arctic vegetation types. Ecol. Monogr. 61:1-31.

Shaver G.R., Giblin, A.E., Nadelhoffer, K.J., and Rastetter, E.B. 1996. Plant functional types and ecosystem change in arctic tundra. In: Smith, T., Shugart, H.H., Woodward, F.I. (Eds.) Plant Functional Types, pp. 152-172. Cambridge University Press, Cambridge.

Shaver G.R. and Kummerow. J. 1992. Phenology, resource allocation, and growth of arctic vascular plants. In: Chapin, F.S.III, Jefferies, R.L., 
Reynolds, J.F., Shaver, G.R., and Svoboda, J. (Eds.), Arctic Ecosystems in a Changing Climate: An Ecophysiological Perspective. pp. 193212.Academic Press, San Diego.

Shaver G.R. and Laundre, J. 1997. Exertion, elongation, and senescence of leaves of Eriophorum vaginatum and Carex bigelowii in Northern Alaska. Glob. Change Biol. 3:146-157.

Shaver G.R. and Jonasson, S. 1999. Response of Arctic ecosystems to climate change: results of long-term field experiments in Sweden and Alaska. Pol Res. 18:245252.

Sitch S., Smith B., Prentice I.C., Arneth A., Bondeau A., Cramer W., Kaplan J.O., Levis S., Lucht W., Sykes M.T., Thonicke K., and Venevsky, S. 2003. Evaluation of ecosystem dynamics, plant geography and terrestrial carbon cycling in the LPJ dynamic global vegetation model. Glob. Change Biol. 9:161-185.

SPSS, Inc. 2002, Rev 11.5. SPSS Inc. Chicago, Illinois .

Starr G., Oberbauer, S.F., and Pop, E.W. 2000. Effects of lengthened growing season and soil warming on the phenology and physiology of Polygonum bistora. Glob. Change Biol. 6:357-369.

Sturm M. Holmgren, J., and Perovich, D.K. 2001 Spacial variation in the winter heat flux at SHEBA: estimates from snow-ice interface temperatures. Ann Glaciol 33:213-220.

Tans P.P., Fung, I.Y., and Takahashi, T. 1990. Observational constraints on the global atmospheric $\mathrm{CO}_{2}$ budget. Science 247:1431-1428.

Tolvanen A. and Henry, G.H.R. 2001. Responses of carbon and nitrogen concentrations in high arctic plants to experimental warming. Can. J. Bot. 79:711-718.

Ulrich A. and Gersper, P.L., 1978. Plant nutrient limitations of tundra plant growth. In: Tieszen, L.L. (Ed.), Vegetation and Production Ecology of an Alaskan Tundra. Ecol. Stud. 29, pp. 457-481. Springer, Berlin.

Vitousek P.M. 1982. Nutrient cycling and nutrient use efficiency. Am. Nat.119:553-572.

Walker D.A., Binnian, E., Evans, BM, Lederer, N.D., Nordstrand, E., and Weber P.J. 1989. Terrain, vegetation and landscape evolution of the R4D research site, Brooks Range Foothills, Alaska. Holarct. Ecol. 12:238-261. 
Walker M.D., Walker, D.A. and Auerbach, N.A. 1994. Plant communities of a tussock tundra landscape in the Brooks Range Foothills, Alaska. J. Veg. Sci. 5:843-866.

Walker D.A., Epstein H.E., Jia G.J., Balser A., Copass C., Edwards E.J., Gould W.A., Hollingsworth J., Knudson J., Maier H.A., Moody A., and Raynolds, M.K. 2003. Phytomass, LAI, and NDVI in northern Alaska: Relationships to summer warmth, soil $\mathrm{pH}$, plant functional types, and extrapolation to the circumpolar Arctic. J. Geophys. Res.-Atmos. 108: 8169

Weih M. 1998. Seasonality of nutrient availability in soils of subarctic mountain birch woodlands, Swedish lapland. Arct. Alp. Res. 30:19-25.

Williams M. and Rastetter, E.B. 1999. Vegetation characteristics and primary productivity along an arctic transect: implications for scaling-up. J. Ecol. 87:885-898.

Wolters V., Silver W.L., Bignell D.E., Coleman D.C., Lavelle P., Van der Putten W.H., De Ruiter P., Rusek J., Wall D.H., Wardle D.A., Brussaard L., Dangerfield J.M., Brown V.K., Giller K.E., Hooper D.U., Sala O., Tiedje J., and Van Veen, J.A. 2000. Effects of global changes on above- and belowground biodiversity in terrestrial ecosystems: Implications for ecosystem functioning. BioScience. 50:1089-1098.

Wookey P.A., Parsons, A.N., Welker, J.M. Potter, J.C., Callaghan, T.V., Lee, J.A., and Press, M.C. 1993. Compare responses of phenology and reproductive development to simulated environmental change in subarctic and high arctic plants. Oikos 67:490-502.

Wookey P.A., Welker, J.M., Parson, A.N., Press, M.C., Callaghan, T.V. and Lee, J.A. 1994. Differential growth allocation and photosynthetic responses of Polygonum viviparum to simulated environmental change at a high arctic polar semi-desert. Oikos 70:131-139.

Zepp R.G., Callaghan T.V., and Erickson, D.J. 2003. Interactive effects of ozone depletion and climate change on biogeochemical cycles. Photochem. Photobio. Sci. 2: 51-61. 